\title{
Michał Kowalski
}

\author{
Uniwersytet Wrocławski \\ http://orcid.org/0000-0002-7320-1140 \\ michal.kowalski@uwr.edu.pl
}

\section{Na polach Treblinki. Profanacja terenów po obozie śmierci w świetle relacji i dokumentów}

\begin{abstract}
Streszczenie
Nowe dokumenty i świadectwa dotyczące znanego, ale nieopisanego do końca procederu profanacji cmentarzyska Treblinki w latach powojennych wskazują, że był to proces powszechny o nie do końca rozpoznanej skali. Rozkopywanie grobów zaczęło się już po ucieczce Niemców w sierpniu 1944 r., a następnie w dużym natężeniu trwało w latach 1946-1947. Świadectwa z tego okresu są zaskakująco zbieżne. Z zebranych materiałów wyłaniają się istotne wątki spontanicznej lub kryminalnej organizacji procederu, istniejącego systemu pośredników sprzedaży znalezionych precjozów czy zadziwiającego paraliżu organów ścigania.
\end{abstract}

\section{Słowa kluczowe}

Treblinka, obóz śmierci, profanacja, antysemityzm, PRL, Żydzi, chłopi

\begin{abstract}
New documents and testimonies concerning the infamous, but incompletely described practice of the profanation of the Treblinka mass graves in the years after the war, show that it was a popular process, the scale of which has not been completely determined. The mass graves began to be dug up immediately after the Germans' escape in August 1944. The practice continued, gaining momentum particularly throughout 1946-1947. Testimonies dating back to that period are surprisingly convergent. From the materials collected emerge important threads of spontaneous or criminal organization of that practice, the system of middlemen who helped sell the unearthed valuables, and the astonishing paralysis of the law enforcement agencies.
\end{abstract}

\section{Key words}

Treblinka, extermination center, profanation, antisemitism, communist Poland, Jews, peasants

„Podczas obławy zauważono około 150 poszukiwaczy złota, z których większa część zdołała zbiec. Zatrzymano około 36 osób i zarekwirowano dwa pierścionki i jedno serduszko złote, które przysyła się do Komendy Wojewódzkiej" - to fragment nieznanego dotychczas meldunku komendanta MO w Sokołowie 
Podlaskim z sierpnia $1945 \mathrm{r}^{1}$ Rozkopywanie pozostałości po obozie śmierci w Treblince jest znanym faktem, ale jego skala może być dużo większa, niż mogłoby się wydawać. Tak przynajmniej wynika z odnalezionych dokumentów dotyczących tego procederu ${ }^{2}$.

Nigdy nierozliczony do końca problem tak zwanych kopaczy, niezmiernie wstydliwej karty polskiej historii, powrócił wraz z książką reportażem pt. Płucz$k i$ autorstwa Pawła Piotra Reszki ${ }^{3}$. Dziennikarzowi „Gazety Wyborczej” udało się przekonać mieszkańców okolic Sobiboru i Bełżca, by opowiedzieli mu o regularnym przekopywaniu terenów poobozowych. W wypadku Treblinki Reszka skupił się jedynie na wyjaśnieniu okoliczności wykonania znanego zdjęcia chłopów i chłopek zatrzymanych w czasie obławy na kopaczy ${ }^{4}$. Fotografię jako pierwsi opublikowali w 2008 r. Marcin Kowalski i Piotr Głuchowski w artykule Gorqczka złota $w$ Treblince $e^{5}$. Autorów oskarżono wówczas, że zdjęcie wykonano w zupełnie innym miejscu, co miało też dyskredytować treść tekstu6. Paweł Piotr Reszka, bazując na dokumentach z archiwum gdańskiego oddziału Instytutu Pamięci Narodowej udowodnił ostatecznie, że zdjęcie to rzeczywiście zostało zrobione na terenach poobozowych $w$ Treblince ${ }^{7}$.

Przeglądając publikacje na temat powojennych losów tego miejsca, można dojść do wniosku, że wciąż brakuje kompleksowego zmierzenia się z ogromem problemu, który tam zaistniał. Poza wspomnianym reportażem z „Gazety Wyborczej” w 2008 r., ukazał się Obóz zagłady Treblinka II w pamięci społecznej

\footnotetext{
${ }^{1}$ Archiwum Instytutu Pamięci Narodowej (dalej AIPN), 00495/57, Meldunki specjalne Komendy Powiatowej MO Sokołów Podlaski 1945, KP MO do Komendy MO Województwa Warszawskiego w Otwocku, 21 VIII 1945 r., k. 58.

${ }^{2}$ We wszystkich cytatach $\mathrm{w}$ artykule zachowano oryginalną pisownię, z jednym wyjątkiem uwspółcześniono w nich interpunkcję, by ułatwić lekturę. Tytuł artykułu nawiązuje do tytułu reportażu Racheli Auerbach Ojf di felder fun Treblinke (jid. Na polach Treblinki) wydanego przez Centralną Żydowską Komisję Historyczną w 1947 r. W dalszej części artykułu wyjaśniam istotność tego tekstu dla opisywanego problemu.

${ }^{3}$ Paweł Piotr Reszka, Płuczki, Poszukiwacze żydowskiego złota, Warszawa: Agora, 2019.

${ }^{4}$ Ibidem, Aneks. Historia pewnej fotografii, s. 203.

${ }^{5}$ Piotr Głuchowski, Marcin Kowalski, Gorq̨czka złota w Treblince, „Gazeta Wyborcza”, dodatek „Duży Format”, 8 I 2008, https://wyborcza.pl/duzyformat/1,127290,4811664.html (dostęp 15 V 2020 r.). Ten tekst przeszedł bez większego echa.

${ }^{6}$ Zob. m.in. Michał Majewski, Paweł Reszka, Katarzyna Staszewska, Treblinka: Tajemnice starej fotografii, „Rzeczpospolita”, 21 I 2011, https://www.rp.pl/artykul/598065-Treblinka--Tajemnice-starej-fotografii.html (dostęp 15 V 2020 r.), oraz tych samych autorów: Reszka i Majewski o Złotych Żniwach Grossów, „Rzeczpospolita”, 20 III 2011, https://www. rp.pl/artykul/629682-Reszka-i-Majewski-o-Zlotych-Zniwach-Grossow-.html (dostęp $15 \mathrm{~V}$ $2020 \mathrm{r}$ ).

${ }^{7}$ Piotr Głuchowski, To był grzech rąbać te ciała i szukać grosza? Wyjaśniona tajemnica zdjęcia hien z Treblinki, „Gazeta Wyborcza”, 18 XI 2019, https://wyborcza.pl/alehistoria /7,121681,25408644,to-byl-grzech-rabac-te-ciala-i-szukac-grosza-wyjasniona.html (dostęp 15 V 2020 r.).
} 


\section{Studia}

(1943-1989) ${ }^{8}$ Martyny Rusiniak, do tej pory jedyna publikacja podejmująca próbę całościowego zbadania tematu ${ }^{9}$. Trzy lata później, w 2011 r., wydano Złote żniwa Jana Tomasza Grossa ${ }^{10}$. W 2012 r. polskiego tłumaczenia doczekał wstrząsający reportaż Na polach Treblinki Racheli Auerbach ${ }^{11}$. Wydaje się więc, że to wciąż niewiele, a sam temat wymaga dalszych badań i poszukiwania materiałów źródłowych, by w pełni ocenić skalę tego zjawiska, a w dalszej kolejności chociażby jego wpływ na tkankę społeczną.

Niniejszy artykuł powstał na podstawie analizy kilku nieznanych wcześniej dokumentów odnalezionych przeze mnie podczas kwerendy dokonywanej w związku z pracą doktorską „Zatruta ziemia. Wpływ obozu śmierci w Treblince na mieszkańców Podlasia Nadbużańskiego 1939/1941-1964" powstającej pod kierunkiem dr hab. Bożeny Szaynok, prof. Uniwersytetu Wrocławskiego. Badania związane z tym tematem prowadzę od kwietnia $2018 \mathrm{r}$. Z aktualnego stanu kwerendy wynika, że liczba źródeł związanych z okresem powojennym na terenie obozu śmierci jest bardzo ograniczona, wiele informacji ma charakter szczątkowy, dokumenty są rozproszone w różnych archiwach, a sprawą profanacji terenów po obozie zajmowały się różne instytucje ${ }^{12}$. Odnalezione źródła w zestawieniu z już znanymi i dokumentami z akt procesu Ludwiga Fischera uprawniają jednak do postawienia pytania o rzeczywistą skalę profanacji treblińskiego cmentarzyska oraz o to, kim byli ludzie, którzy w niej uczestniczyli.

\footnotetext{
${ }^{8}$ Martyna Rusiniak, Obóz zagłady Treblinka II w pamięci społecznej (1943-1989), Warszawa: Neriton, 2008.

${ }^{9}$ Martyna Rusiniak-Karwat poruszyła ten temat również w artykule Okres profanacji i zapomnienia. Treblinka II [w:] Co wiemy o Treblince? Stan badań, red. Edward Kopówka, Siedlce: Muzeum Regionalne w Siedlcach, 2013.

${ }^{10}$ Jan Tomasz Gross, współpraca Irena Grudzińska-Gross, Złote żniwa. Rzecz o tym, co się działo na obrzeżach zagłady Żydów, Kraków: Znak, 2011.

${ }^{11}$ Rachela Auerbach, Treblinka. Reportaż, tłum. Karolina Szymaniak, „Zagłada Żydów. Studia i Materiały" 2012, nr 8, s. 25-75. Wydanie w jidysz, języku oryginału: Ojf di felder fun Treblinke, Łódź: CŻKH, 1947. Wydanie to zawierało również zdjęcia z terenu obozu.

${ }^{12}$ Obóz śmierci Treblinka II był ulokowany na terenie powiatu sokołowskiego, w gminie Kosów Lacki, jego część należała też do nieistniejącej obecnie gminy Prostyń (powiat węgrowski). Zajmowali się nim zarówno atarosta powiatowy w Sokołowie Podlaskim, jak i Węgrowie, a także wojewoda warszawski, powiatowe urzędy bezpieczeństwa publicznego (Węgrów i Sokołów), komendy MO na poziomie powiatu, wojsko stacjonujące w Ostrowi Mazowieckiej i inne instytucje. Kwerenda związana z niniejszym artykułem obejmowała Archiwum Państwowe w Siedlcach, Archiwum Państwowe w Warszawie, AIPN, Archiwum Żydowskiego Instytutu Historycznego, Archiwum Yad Vashem, zbiory United States Holocaust Memorial Museum. Artykuł dotyczy okresu od sierpnia 1944 do 1949 r., czyli lat największego natężenia profanacji terenu po obozie.
} 


\section{„Sporządzaliśmy obławy, przepędzając hieny ludzkie"}

Obóz śmierci Treblinka II przestał istnieć 17 listopada 1943 r. Jego ostatni komendant miał zatrzeć ślady zbrodniczej działalności, budynki zniszczyć, a obszar obozu zaorać, obsiać łubinem i zasadzić sosny. W roli strażników terenu powołano Niemca z Ukrainy Strebla i Saszkę - Ukraińca, którzy wraz ze swoimi rodzinami zamieszkali $\mathrm{w}$ domu wykonanym $\mathrm{z}$ cegieł po rozebranych krematoriach. Obok niego stały jeszcze obora, drewniana stodoła i barak. W "gospodarstwie" uprawiano warzywa, hodowano konie, świnie, krowy ${ }^{13}$. Dwa kilometry dalej wciąż funkcjonował obóz pracy Treblinka I. Niemcy zlikwidowali go dopiero 23 lipca 1944 r., „kiedy więźniowie usłyszeli pierwsze odgłosy artylerii radzieckiej"14. 11 sierpnia oddziały Armii Czerwonej weszły do oddalonego o 12 km od Treblinki Kosowa Lackiego, a chwilę później na obszar poobozowy.

Pierwszą, obszerną relację o tym, jak wyglądał ten teren po wyzwoleniu, sporządził Wasilij Grossman, autor słynnego dzieła Życie i $\operatorname{los}^{15}$. Na początku września 1944 r. pojawił się w Treblince jako korespondent wojenny „Krasnej Zwiezdy". To, co zobaczył i usłyszał, zamieścił w artykule Piekło Treblinki - szczegółowym i analitycznym tekście na temat zarówno obozu śmierci Treblinka II, jak i obozu pracy Treblinka I (wykorzystano go później jako dowód w procesie norymberskim). Dzięki niemu wiemy też, jak wyglądały ich pozostałości. To obraz zaskakujący, ponieważ to, co widział Grossman, kompletnie nie pasuje do mitu zadbanego "gospodarstwa" i skutecznie zatartych wszystkich śladów zbrodni.

Oto na wpół zgniłe koszule, spodnie, spleśniałe obuwie, papierośnice, zegarki, scyzoryki, przybory do golenia, obuwie dziecięce, chustki z deseniami po brzegach, bielizna koronkowa, gorsety, podwiązki. Nieco dalej widnieją naczynia: kubki, filiżanki, garnki, dzbany, blaszanki, kociołki. A jeszcze dalej wyzierają z ziemi sowieckie paszporty, notesiki bułgarskie, fotografie dzieci warszawskich, dzieci z Wiednia, kartki pokryte niezgrabnym dziecięcym pismem, zbiorek poezji, jakaś modlitwa przepisana na skrawku papieru, niemieckie kartki żywnościowe... Wszędzie pełno flakoników, buteleczek zielonych i niebieskich, zawierających niegdyś perfumy ${ }^{16}$.

\footnotetext{
${ }^{13}$ Rusiniak, Obóz zagłady Treblinka II w pamięci społecznej..., s. 21-22.

${ }^{14}$ Wasilij Grossman, Piekło Treblinki. Reportaż literacki, Katowice: Wydawnictwo „Literatura Polska", 1945, s. 4.

${ }^{15}$ Wasilij Grossman, Życie i los, tłum. Jerzy Czech, Warszawa: W.A.B., 2009. Grossman złożył rękopis w wydawnictwie w $1960 \mathrm{r}$. W lutym następnego roku mieszkanie pisarza przeszukało KGB. Zabrano wszystkie kopie dzieła, a nawet maszyny do pisania. Książkę uznano za zagrożenie dla ustroju. Przetrwała dzięki temu, że autor oddał dwie kopie swoim przyjaciołom. Po śmierci Grossmana w 1964 r. nielegalnie wywieziono ją na Zachód, gdzie odniosła wielki sukces wydawniczy.

${ }^{16}$ Grossman, Piekło Treblinki..., s. 31.
} 


\section{6}

Zamiast spokojnie rosnącego łubinu Grossman zastaje obraz przepełniony upiornym chaosem: „Nagle przystanęliśmy. Grube ondulowane, delikatne lekkie, cudowne włosy dziewcząt całymi puklami leżały na białym piasku, a nieco dalej wspaniały ciężki, czarny warkocz. Musiała to być niewątpliwie zawartość jakiegoś zapomnianego worka, do którego wkładano włosy kobiet. Więc to była prawda! Ostatnia szalona nadzieja, że to wszystko było tylko widziadłem, rozwiała się"17.

Owa niespójność obrazu, w którym Treblinka II kończy działalność, a ślady zostają zatarte przez Niemców skutecznie i skrupulatnie, z powojennym nieładem, gdy Grossman wręcz potyka się o dowody zbrodni, pojawia też we wszystkich znanych świadectwach tego okresu ${ }^{18}$.

Pisarz nie sprecyzował, kiedy dokładnie przyjechał do byłego obozu śmierci, ale mniej więcej w tym samym czasie, 15 września 1944 r., przybyła tam Polsko-Radziecka Komisja do Badania Zbrodni Niemieckich. W jej skład wchodził m.in. Mirosław Chodźko, były więzień obozu pracy Treblinka I. Jego relacja różni się od tej Grossmana jedynie mniejszą liczbą opisanych detali: „wielka jest ilość rozrzuconych i zniszczonych rzeczy domowego użytku, jak misy, kubki, widelce, zabawki dziecinne, strzępy dokumentów i książek, podarte ubrania, a także dużo obuwia wszystkich rozmiarów i fasonów"19. Obie wizyty dzieli zapewne kilka dni różnicy. Z tego czasu pochodzą również prawdopodobnie wykonane przez Rosjan fotografie „Novosti Press" ${ }^{20}$. Na jednej z nich widzimy dokładnie taki sam obraz terenu jak w obu cytowanych opisach. Ich autorzy niczego nie dodawali. We wrześniu 1944 r. panował tam przygnębiający olbrzymi zamęt.

W tym kontekście zastanawiające są daty. Dwie rodziny strażników uciekły $\mathrm{z}$ „gospodarstwa” tuż przed wojskami radzieckimi, prawdopodobne w czasie likwidacji obozu Treblinka I, czyli pod koniec lipca lub na początku sierpnia 1944 r. $^{21}$ Tymczasem już we wrześniu tego roku, zaledwie miesiąc później, poobozowy teren wygląda tak, jakby go ktoś zdemolował. Kto? Zniszczeń mogli dokonać radzieccy żołnierze. Front przeszedł przez powiat sokołowski w sierpniu 1944 r., a we wrześniu był już 70 km dalej, w okolicy Serocka, na północ od Warszawy, na linii Narwi i Bugu ${ }^{22}$. W warunkach wojny wszystko było możliwe. Tak jak jest możliwe, że rozkopywanie grobów przez okoliczną ludność zaczę-

\section{${ }^{17}$ Ibidem.}

${ }^{18}$ Uwagę na ten problem zwróciła Caroline Sturdy Colls, zob. eadem, O tym, co minęło, lecz nie zostało zapomniane. Badania archeologiczne na terenie byłego obozu zagłady $w$ Treblince, tłum. Ewa Felska, Jerzy Giebułtowski, „Zagłada Żydów. Studia i Materiały” 2012, nr 8, s. 83-118.

${ }^{19}$ Archiwum Żydowskiego Instytutu Historycznego (dalej AŻIH), Pamiętniki Żydów ocalałych z Zagłady, 302/321, Mirosław Chodźko, „Treblinka dziś”, k. 104.

${ }^{20}$ Fotografia oznaczona „TURNED UP EARTH \#1”, http://www.deathcamps.org/treblinka/ lasttracks.html (dostęp 15 V 2020 r.).

${ }^{21}$ Rusiniak, Obóz zagłady Treblinka II w pamięci społecznej..., s. 22.

22 Tadeusz Sawicki, Działania wojenne na Podlasiu, „Szkice Podlaskie” 1994, nr 4, s. 49. 
ło się zaraz po ucieczce Niemców. Ktoś musiał być przecież pierwszy. A już na zdjęciu z „Novosti Press” widać wyraźnie liczne doły i dołki, pofałdowania terenu - efekty takiego właśnie działania. W dalszym ciągu artykułu postaram się odpowiedzieć na powyższe pytanie.

Dokładne wyjaśnienie tego, co działo się na obszarze poobozowym w sierpniu 1944 r., jest trudne, podobnie jak rekonstrukcja wydarzeń od wizyty Grossmana aż do sierpnia 1945 r. - czyli przez cały kolejny rok!'23 Źródła są bardzo skąpe. Trwała wojna. Rzeczywistość na wyzwolonych terenach była dramatyczna. „Z wyjątkową skrupulatnością niszczono wsie Nadbuża [...]. Ogółem oddziały niemieckie spaliły całkowicie 11 wsi, a 20 częściowo. Palono również zboże, siano w stertach na polu, wycinano drzewa oraz zrabowano - nieukryty w porę przez rolników inwentarz żywy" ${ }^{24}$. W powiecie powoli instalowały się nowe władze, ale cierpiały na brak wszystkiego, od kadr zaczynając, na paliwie do samochodów kończąc. Zabójstwa i kradzieże, rozboje, rabunki były niemalże codziennością. Chaos pogłębiała działalność silnych, dobrze uzbrojonych grup przeciwników nowego reżimu. $\mathrm{W}$ takich warunkach nikt nie myślał o jakimkolwiek stałym zabezpieczeniu terenów poobozowych.

Kolejny, a pierwszy z odnalezionych dokumentów dotyczących terenu Treblinki nosi datę 27 sierpnia 1945 r. i opisuje już intensywne przekopywanie cmentarzyska. Szef Komendy Milicji Obywatelskiej w Sokołowie Podlaskim raportował w nim przebieg obławy na „poszukiwaczy złota” z 21 sierpnia, którą zorganizował i przeprowadził razem z funkcjonariuszami lokalnego Urzędu Bezpieczeństwa:

Dzisiejsza obława przeprowadzona była na podstawie donosu tamtejszej ludności, która do kopiących złoto nie przyłącza się. Podczas obławy zauważono około 150 poszukiwaczy złota, z których większa część zdołała zbiec. Zatrzymano około 36 osób i zarekwirowano 2 pierścionki i jedno serduszko złote, które przesyła się do Komendy Wojewódzkiej. Inną część zarekwirowanych rzecz Urząd Bezpieczeństwa zatrzymał u siebie ${ }^{25}$.

W cytowanym źródle padają jeszcze inne ważne informacje. „Od dłuższego czasu okoliczna ludność trudni się zbieraniem złota na terenach, które swego czasu włączone były do obozu «Treblinka». W poszukiwaniu złota ludzie ci wykopują szczątki rozkładających się zwłok, wobec czego nad całą okolicą unosi się przykry, grożący epidemią zapach" - czytamy w meldunku.

Komendant określa obławę mianem „dzisiejszej”, a więc na polach był nie po raz pierwszy. Jako sprawców procederu wskazał „okoliczną ludność, przeko-

\footnotetext{
${ }^{23} \mathrm{Z}$ tego miesiąca pochodzi kolejny datowany dokument odnaleziony w czasie kwerendy.

${ }^{24}$ Kazimierz Witt, Sokołów Podlaski w latach 1939-1950 [w:] Dzieje Sokołowa Podlaskiego i jego regionu, red. Józef Kazimierski, Warszawa: PWN, 1982, s. 231.

${ }^{25}$ AIPN, 00495/57, KP MO do Komendy MO Województwa Warszawskiego w Otwocku, 21 VIII 1945 r., k. 68.
} 
pującą miejsca pogrzebania ofiar zbiorowego mordu „od dłuższego czasu”. Nie wszyscy brali w tym udział, ale by powstrzymać proceder - złożyli donos. Musieli być zatem w mniejszości bądź też stanowili grupę słabszą, obawiającą się konsekwencji otwartego przeciwdziałania. Nic dziwnego - 150 osób w jednym czasie $w$ takim miejscu dowodzi, że proceder nie był marginalny.

13 września 1945 r. w Treblince pojawili się kolejni świadkowie - Michał Kalembasiak i Karol Ogrodowczyk ${ }^{26}$. Swoje wrażenia z wizyty zapisali w protokole dla Wojewódzkiej Żydowskiej Komisji Historycznej w Warszawie.

Mniej więcej o jakieś 3 kilometry od Treblinki uderzył nas niesamowity odór trupi [...]. Po przybyciu na miejsce [...] pole było tak zryte, że w niektórych miejscach były doły do 10-ciu metrów głębokich [sic!], w niektórych widniały szczątki kości ludzkich, piszczele, szczęki, nogi itp. Pod każdym drzewkiem były otwory wykopane przez poszukiwaczy złota, brylantów. Odór trupi i gazu tak nas odurzył, iż poczęliśmy z kolegą wymiotować i czuliśmy drapanie niesamowite $\mathrm{w}$ gardle ${ }^{27}$.

Świadkowie spotkali na miejscu grupę ludzi z łopatami, którzy na ich widok zaczęli uciekać. Obławy opisane przez komendanta z Sokołowa nikogo zatem nie odstraszały. Można też zastanowić się nad ich rzeczywistą częstotliwością, skoro służby nowej władzy były w fatalnej kondycji. „Dziwię się, że miejsce uświęcone męczeńską śmiercią [...] nie zostało dotychczas zabezpieczone przed grabieżą i chciwością okolicznych kmiotków, którzy w ohydny sposób profanują to miejsce, podkopując drzewa, krzaki i ryjąc doły w ziemi wydobywając stamtąd na wpół spalone szczątki ludzkie"28 - pisał Kalembasiak. Na miejscu nie było żadnej ochrony, a w okolicy panowały „niesamowite stosunki” związane z napadami na gospodarzy podejrzewanych o posiadanie precjozów $\mathrm{z}$ obozu ${ }^{29}$.

${ }^{26}$ Michał Kalembasiak był urzędnikiem państwowym mieszkającym przed wojną w Warszawie, który podczas okupacji osiadł we wsi Złotki - 4 km od Treblinki. Po wojnie przyjechał na teren Treblinki z kolegą Karolem Ogrodowczykiem, spisał świadectwo/relację ze stanu obozu. Działał prawdopodobnie z własnej inicjatywy.

${ }^{27}$ AŻIH, Relacje Żydów ocalałych z Zagłady, 301/4867, Protokół Michała Kalembasiaka i Karola Ogrodowczyka dla WŻKH w Warszawie, [po 13 IX 1945 r.], s. 1. Do raportu dołączono 21 zdjęć wykonanych w czasie wizytacji.

${ }^{28}$ Ibidem, s. 2.

${ }^{29}$ Ibidem, s. 3. Kalembasiak i Ogrodowczyk przytaczają historię kobiety „przypiekanej” na ogniu, by wydała miejsce schowanych kosztowności. Paweł Reszka w Płuczkach ustalił, że była to siostra Stanisława K. ze wsi Maliszewa Nowa, który trudnił się przeczesywaniem terenu obozowego. Reszka używa sformułowania „na piecu”, a w tym zeznaniu świadka jest mowa o posadzeniu kobiety na kuchnię (Reszka, Płuczki..., s. 210). W domach na podlaskiej wsi używano do przyrządzania posiłków starego typu kuchni opalanych drewnem, z żeliwną płytą, która podczas użycia było bardzo rozgrzana. Już sama świadomość wykonania groźby przyłożenia do niego części ciała mogła być wystarczającym „argumentem” do wyjawienia posiadanych informacji. 
Owa „niesamowitość” dotyczy również aspektu, jaki pojawia się w meldunku komendanta milicji z Kosowa Lackiego do prokuratora Sądu Okręgowego w Siedlcach z 29 września 1945 r.:

Sporządzaliśmy obławy, przepędzając hieny ludzkie, które uparcie wracały, by nadal prowadzić przerwane poszukiwania. Teren ten strzeżony był przez nieznane osoby posiadające broń, które zabraniały wstępu dla osób niewtajemniczonych i stanowiły Straż Ochronną dla wydobywających szczątki zegarków, biżuterii, pieniędzy, przedstawiających mniejszą lub większą wartość. Stan taki doprowadził do zatarcia śladów miejsca masowej zbrodni niemieckiej i groził wytworzeniem się epidemii chorób ludzkich ${ }^{30}$.

Wzmianka o „nieznanych osobach posiadających broń”, tworzących bliżej nieokreśloną Straż Ochronną, może prowadzić do wniosku, że jesienią $1945 \mathrm{r}$. w okolicy obozu istniała jakaś szajka, „porządkująca” proceder.

$\mathrm{Z}$ raportu komendanta $\mathrm{z}$ Kosowa dowiadujemy się również, że w czasie obław stosowano nawet miny przeciwpiechotne. Podczas jednej $\mathrm{z}$ takich zasadzek zginęły trzy osoby. Ciał nie udało się zidentyfikować. Trudno o bardziej drastyczny sposób walki z tak odrażającym procederem. Mógł być to wręcz akt desperacji. Objaw bezradności. Komendant wspomina przecież w tym meldunku o kilkudziesięciu kolejnych zatrzymanych osobach ${ }^{31}$.

W Archiwum IPN znajduje się „Spis ofiar II wojny światowej 1939-1945 powiatu Sokołów Podlaski" autorstwa Józefa Maleszewskiego, wykonany w 1983 r. prawdopodobnie na podstawie wywiadów zebranych w poszczególnych miejscowościach regionu. W spisie tym znajdują się dwa szczególne przypadki. Według tego źródła 16-letni Rafał Gierej, mieszkaniec wsi Guty ${ }^{32}$, „zginął w 1945 roku w Treblince, szukając złota”. Takie samo zdanie widnieje obok nazwiska Maliszewski - 20-latka ze wsi Maliszewa ${ }^{33}$. On również „zginął w Treblince przy szukaniu złota" ${ }^{34}$. Obie te miejscowości leżą w najbliższym sąsiedztwie obozu. Czy są to ofiary jednej z obław z użyciem min? A może zginęli w innych okolicznościach?

Kalembasiak i Ogrodowczyk wykonali serię zdjęć pokazujących aktualny stan terenu poobozowego. W porównaniu z fotografiami rosyjskimi z września

\footnotetext{
${ }^{30}$ AIPN, Obozy, 66, k. 2, cyt. za: Rusiniak, Obóz zagłady Treblinka II w pamięci społecznej..., s. 31.

${ }^{31}$ Podczas kwerendy nie znalazłem rozstrzygnięcia tych spraw na poziomie procesów sądowych. Być może część z nich w ogóle nie trafiła do sądów, a złapanych karano doraźnie szarwarkiem (ten wątek poruszam w dalszej części artykułu).

${ }^{32}$ Guty - wieś w pobliżu Treblinki, około $8 \mathrm{~km}$ na południe od terenu obozu śmierci.

${ }^{33}$ Istnieje Stara i Nowa Maliszewa. Nazwa Maliszewa odnosi się do obu. To wieś, która leżała w bezpośrednim sąsiedztwie obozu pracy w Treblince i tzw. Lasu Maliszewskiego, gdzie rozstrzeliwano więźniów obozu. W linii prostej od obozu śmierci dzieliło tę wieś około 6 kilometrów.

${ }^{34}$ AIPN, GK 166/1185, Spis ofiar II wojny światowej 1939-1945 powiatu Sokołów Podlaski, k. 29.
} 
1944 r. widok znacząco się zmienił. Chaos był jeszcze większy, a dodatkowo pojawiły się głębokie leje i wykopy, o których pisali w swoim raporcie. Skala zniszczeń była porażająca. „Dla skopania terenu tego, mającego jakieś $2 \mathrm{~km}$ kwadratowe, musiało pracować tysiące ludzi, gdyż ogrom rozkopanych dołów jest kolosalny” - czytamy w raporcie ${ }^{35}$. „Tysiące” to bardzo nieostre określenie, ale zauważmy - w ciągu roku od wejścia Armii Czerwonej w zaledwie dwóch meldunkach komendantów z Sokołowa (150) i Kosowa (kilkudziesięciu) podano łącznie liczbę około 200 osób zaobserwowanych na terenie obozu. A wiemy, że obław było więcej.

Krajobraz rozrytej i rozszarpanej gleby wymieszanej ze szczątkami ludzkimi, kośćmi, czaszkami, przedmiotami codziennego użytku wyłania się również z kolejnej dokumentacji fotograficznej - sporządzonej przez Zdzisława Łukaszkiewicza, sędziego śledczego z Siedlec, i Jerzego Maciejewskiego, prokuratora tamtejszego Sądu Okręgowego. W listopadzie 1945 r. przeprowadzili oni na obszarze obozu czynności śledcze zlecone im przez Główną Komisję Badania Zbrodni Niemieckich w Polsce.

Obaj wizytowali były obóz śmierci kilka razy - w dniach $6-7,9-13$ oraz 15 listopada 1945 r. Podczas pierwszego pobytu towarzyszyli im byli więźniowie Treblinki II, m.in. Samuel Rajzman i Henryk Rajchman (Romanowski), oraz Rachela Auerbach, przedstawicielka Centralnej Żydowskiej Komisji Historycznej w Polsce. To właśnie po tej wizycie napisała wspomniany reportaż Na polach Treblinki. Poruszona do głębi, relacjonowała:

Przychodzą tu wszelkiej maści szabrownicy i maruderzy - z łopatami, całe grupy. I kopią, szukają, ryją. Przesiewają piasek, wyciągają z ziemi na wpół rozłożone części ciała, kości, rozrzucone szczątki, licząc, że natrafią choćby na jakąś monetę, na jeden złoty ząb. Taszczą tu nawet niewypalone pociski i bomby - ludzkie szakale i hieny. Podkładają kilka naraz, robiąc ogromne dziury w zbezczeszczonej, przesiąkniętej krwią, wymieszanej z popiołem spalonych Żydów ziemi... ${ }^{36}$

Jej reportaż nie pozostawia złudzeń co do wyglądu terenu poobozowego w listopadzie $1945 \mathrm{r}$.

Bomby odsłoniły wnętrze zbezczeszczonej ziemi. Kości nóg, żebra, kawałki kręgosłupów, czaszki, większe i mniejsze, krótkie i długie, okrągłe i owalne [...] - Worek, czy ktoś ma worek? Weźmy ze sobą worek z kośćmi! [...] Spójrz, tam na brzegu tamtej dziury - mówi sędzia - leży szkielet dziecięcej nóżki. Jeden z ocalonych biegnie w tamtą stronę. - Uważaj - ostrzega go drugi - na nóżce wisi jeszcze kawałek ciała. Ale ten, który po nią poszedł, owija ją w ga-

${ }^{35}$ AŻIH, 301/4867, Protokół Michała Kalembasiaka i Karola Ogrodowczyka dla WŻKH w Warszawie, s. 2.

${ }^{36}$ Auerbach, Treblinka. Reportaż..., s. 72. 
zetę, jak pobożny Żyd zwykła zawija etrog. Owija kość w połę płaszcza, a następnie wkłada do kieszeni i przytula do serca ${ }^{37}$.

Protokół czynności sądowych śledczych jest formalny i suchy. W kwestii ustaleń nie różni się od wcześniejszej obserwacji Auerbach. Sędzia Łukaszkiewicz pisał:

Cały teren obozu pokryty jest obecnie różnej wielkości dołkami, dołami i lejami. Znajdują się one wszędzie, nawet w miejscach porośniętych lasem, najczęściej jednak grupują się na [...] wzniesieniu, gdzie na przestrzeni około 2 ha każda dosłownie część terenu jest nimi pokryta. Głębokość niektórych lejów sięga do 7 metrów, a średnica do 25 metrów. W pobliżu lejów znajdują się niewypały bomb lotniczych i pocisków artyleryjskich oraz liczne odłamki [...]. W opisanej części terenu pokryte[go] wykopami i lejami napotyka się liczne szczątki ludzkie (czaszki i inne kości); na niektórych kościach widać jeszcze resztki tkanki, a na czaszkach resztki włosów. Pozatem cały teren pokryty jest popiołami, wymieszanymi z piaskiem i żwirem, tak że na tym obszarze nie ma właściwie czystych warstw piasku i żwirku. W popiołach widoczne są szczątki kości ludzkich. Świadkowie Rajzman i Romanowski wyjaśniają, że na tym miejscu znajdowały się właśnie doły, w których grzebano trupy, a później paleniska zwłok ${ }^{38}$.

Jak wyjaśnił obecnym przy oględzinach terenu Stanisław Kucharek, sołtys wsi Wólka Okrąglik ${ }^{39}$, dołki i doły wykopała okoliczna ludności w poszukiwaniu złota i kosztowności, natomiast leje powstały w wyniku wysadzania bomb lotniczych i pocisków przez żołnierzy jednostki Armii Czerwonej stacjonującej przy stacji kolejowej w Kosowie Lackim ${ }^{40}$. Jak widać, był doskonale zorientowany w sprawach obozu, a jego obecność w komisji raczej nie była przypadkowa.

W ramach prowadzonych czynności śledczych dokonano próbnych rozkopów. W różnych dniach zajmowało się tym od 20 do 35 robotników w ramach szarwarku ${ }^{41}$. Zaskakuje liczba i wielość przedmiotów wykopywanych z ziemi, szczególnie $\mathrm{w}$ zderzeniu z mitem o skutecznym zatarciu śladów obozu przez Niemców. 9 listopada - „w toku pracy natrafiono na liczny bilon polski, a nadto rosyjski, niemiecki, austryjacki i czeski oraz szczątki różnego rodzaju naczyń", 10 listopada - „natrafiono na szereg częściowo lub całkowicie zniszczonych do-

${ }^{37}$ Ibidem, s. 73-74.

${ }^{38}$ AIPN, GK 196/69, Protokół czynności wykonanych w terenie w toku dochodzenia sądowego w sprawie obozu śmierci w Treblince, k. 97.

${ }^{39}$ Wólka Okrąglik - wieś leżąca w bezpośrednim sąsiedztwie obozu.

${ }^{40}$ Zgodnie z komunikatem Żydowskiej Agencji Prasowej bomby miały pochodzić z małego lotniska polowego we wsi Ceranów, położonej $16 \mathrm{~km}$ od Treblinki. W cytowanym protokole wyraźnie jest wskazany Kosów Lacki. Natomiast obie te informacje można traktować zbieżnie. Bomby mogły pochodzić z Ceranowa, a na pola Treblinki mogli dostarczać je żołnierze stacjonujący w Kosowie Lackim. Ceranów i Kosów dzieli 6 km.

${ }^{41}$ Szarwark - roboty publiczne wykonywane na rzecz gromady wiejskiej, które co do zasady były nieodpłatne i przymusowe. 


\section{Studia}

kumentów polskich, niemiecką kartę rozpoznawczą żydowską w stanie bardzo zniszczonym oraz znowu bilon polski, rosyjski, belgijski, a nawet amerykański", 13 listopada zaś - „obok znajdowanego dotychczas bilonu natrafiono tu również na bilon grecki, słowacki i francuski oraz dokumenty w języku hebrajskim, polskim i szczątki sowieckiego paszportu"42. Oprócz monet wymienionych już państw wykopano także bułgarskie lewy, rumuńską 1 leję, czesko-słowackie korony i halerze, oraz dwa półguldeny Wolnego Miasta Gdańska ${ }^{43}$.

Należy też odnotować, że robotnicy szarwarkowi, przydzieleni śledczym z Siedlec, a wyznaczeni do pracy przez Zarząd Gminy z Kosowa, byli znakomicie zorientowani w topografii terenu. „Rozpoczęto rozkopywanie dołu - śmietnika w północno-zachodniej części obozu. W miejscu tym, jak oświadczyli robotnicy pochodzący z sąsiednich wiosek, znajdowano dotychczas największą liczbę dokumentów"44. Skąd mogli to wiedzieć? Możliwe, że zatrzymano ich podczas obław, a szarwark był rodzajem kary. Ta hipoteza opiera się na innym dokumencie, odnalezionym również w czasie kwerendy. Będzie o nim jeszcze mowa.

Sędzia Łukaszkiewicz natrafił na jeszcze inne rzeczy pochodzące z terenu obozu. 18 października 1945 r. wystąpił do Milicji Obywatelskiej w Sokołowie Podlaskim o dostarczenie „wszystkich dowodów rzeczowych znajdujących się w posiadaniu Milicji Obywatelskiej, a dotyczących obozu". Dzień później, 19 października, dowody rzeczowe w ekspresowym tempie dowieziono do siedleckiego sądu. W worku o wadze 3,11 kg znajdowały się różne monety, części do zegarków, okularów, broszki, łańcuszki i nieznane bliżej różne popalone części metalowe ${ }^{45}$. Szczegółowe oględziny zawartości odbyły się 20 grudnia $1945 \mathrm{r}$. W protokole opisano kilka medali, odznakę milicjanta żydowskiego nr 57, kopertę zegarka z rosyjskim napisem, różnego rodzaju osobiste medaliony: jeden w kształcie serca z napisem w języku rosyjskim, drugi z portretem Bejlisa i napisami w języku rosyjskim i hebrajskim, trzeci z wizerunkiem Mojżesza i napisem „Rachela”, krzyż z datami 1914-1918, a także krzyżyk i medalik katolicki z napisem polskim ${ }^{46}$.

Proceder profanacji dotyczył zarówno obszaru po obozie śmierci, jak i tego po pobliskim obozie pracy Treblinka I. Sędzia Łukaszkiewicz prowadził tam czynności również w listopadzie 1945 r., poszukując m.in. grobów zbiorowych. W obozie tym aż do dnia likwidacji 23 lipca 1944 r. żyła i pracowała grupa ponad

\footnotetext{
${ }^{42}$ AIPN, GK 196/69, Protokół czynności wykonanych w terenie w toku dochodzenia sądowego w sprawie obozu śmierci w Treblince, k. 103.

${ }^{43}$ Ibidem, Protokół oględzin bilonu stanowiącego dowód rzeczowy, k. 122.

${ }^{44}$ Ibidem, Protokół czynności wykonanych w terenie w toku dochodzenia sądowego w sprawie obozu śmierci w Treblince, k. 103. 9 XI 1945 r. w pracach wzięło udział 20 robotników szarwarkowych, 10 listopada - 35, a 13 listopada - 30.

${ }^{45}$ Ibidem, Wykaz przesłanych do Sądu Grodzkiego dowodów rzeczowych dotyczących obozu w Treblince, k. 96.

${ }^{46}$ AIPN, GK 196/70, Protokół oględzin przedmiotów pochodzących z obozu śmierci w Treblince, k. 1.
} 
500 Żydów - mężczyzn i kobiet, których tego dnia rozstrzelano w lesie między wsią Maliszewa a obozem ${ }^{47}$.

Jest to niezbyt stary las sosnowy. Mniej więcej na wprost obozu znajduje się w nim wycięta linia o szerokości 10 metrów. W czasie oględzin stwierdzono tu 17 grobów masowych, prócz tego w lesie opodal znaleziono dalsze 24 groby masowe.

Oprócz ofiar z sierpnia znaleziono tam zwłoki więźniów z całego okresu działania obozu. „Wszystkie ujawnione groby w czasie dokonywania oględzin były już naruszone (rozkopane przez nieznanych sprawców), przy czym zwłoki zostały rozrzucone" - napisał śledczy ${ }^{48}$.

Bezpośrednim skutkiem tego, co zobaczyli przedstawiciele CŻKH podczas wizyty w listopadzie 1945 r., była depesza Żydowskiej Agencji Prasowej o bezczeszczeniu grobów żydowskich w Treblince. „Skonstatowano następnie - na zasadzie zeznań świadków - że ludność okoliczna gromadami dokonuje na piaszczystym terenie rozkopów w celu wydobycia znajdujących się rzekomo w grobach skarbów” - czytamy w niej. I dalej: „na skutek tych rozkopów wyrównana i obsiana łubinem ziemia ujawniła swoje wnętrze, pełne jeszcze niespalonych względnie niestrawionych przez glebę szczątków ludzi i należących do nich przedmiotów". Tekst powtarza obserwacje śledczych z Siedlec: używanie bomb lotniczych do wysadzania dołów, chaos, brak ogrodzenia oraz ponury krajobraz okolicy. Kończy się apelem:

Jak wynika z opisanego wyżej stanu rzeczy, mamy w Treblince do czynienia ze świadomą profanacją zwłok i prochów ludzi umęczonych przez katów niemieckich, jako też szkodliwym niszczeniem dowodów przestępstw niemieckich. Profanacja ta hańbi i obraża uczucia żydostwa w Polsce i na całym świecie. Należy jak najrychlej położyć kres temu bezczeszczeniu zbiorowych mogił oraz świętego dla wszystkich żydów w Polsce i na całym świecie miejsca kaźni milionów bezbronnych i niewinnych ofiar żydowskich ${ }^{49}$.

\section{„Teren nie jest ogrodzony i groby nie są zabezpieczone”}

12 grudnia 1945 r. Departament Polityczny Ministerstwa Administracji Publicznej zażądał od wojewody warszawskiego ${ }^{50}$ wszczęcia odpowiednich kroków „celem przeciwdziałania profanacji”. Do pisma dołączono artykuł ŻAP,

${ }^{47} \mathrm{Z}$ grupy tej według Łukaszkiewicza ocalały trzy osoby, ale ocalonych było więcej. W trakcie prowadzonych badań udało mi się ustalić personalia i losy pięciu kolejnych uciekinierów.

${ }^{48}$ Zdzisław Łukaszkiewicz, Streszczenie wyników śledztwa sq̨dowego, „Biuletyn Głównej Komisji Badania Zbrodni Niemieckich w Polsce" 1946, t. 1, s. 121.

${ }^{49}$ AŻ̇H, Komisja dla badania zbrodni niemieckiej w Treblince, „Biuletyn ŻAP”, 23 XI 1945, nr 104 (114), s. 3-4.

${ }^{50}$ Pełniącym obowiązki wojewody był wówczas Stanisław Zrałek (do 15 XII 1945 r.), a następnie Wilhelm Garncarczyk (do 27 III 1947 r.). 


\section{Studia}

o którym była mowa wcześniej ${ }^{51}$. Dopiero jednak miesiąc później, 4 stycznia 1946 r., wojewoda wysłał krótką notkę do starosty powiatowego w Sokołowie ${ }^{52}$, polecając mu „wszczęcie energicznych kroków” w przedmiotowej sprawie. Odpowiedzi starosty nie udało się odnaleźć, ale 6 lutego 1946 r. wojewoda warszawski odpisał do ministerstwa, że informacja Żydowskiej Agencji Prasowej „nie odpowiada rzeczywistości”, jego zdaniem bowiem „specjalne oddziały na rozkaz Ministerstwa Obrony Narodowej dokonywały poszukiwań dokumentów i śladów tożsamości ofiar pochowanych na cmentarzu o przestrzeni około

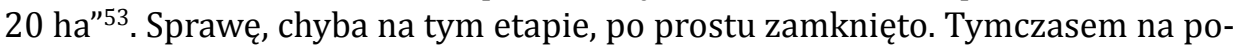
lach Treblinki nic się nie zmieniło.

Kolejny dokument na ten temat pochodzi z lutego 1946 r., a więc z okresu zimy. Wydawałoby się, że warunki atmosferyczne i zmarznięta ziemia mogą przeszkadzać w jej przekopywaniu. Nic bardziej mylnego. Komendant powiatowy MO w Sokołowie w meldunku z 16 lutego donosił, że we wsi Żochy ${ }^{54}$, w gminie Chruszczewka, zainstalowała się „banda w okolicy 200 osób”55, która „dokonywała systematycznej obławy na uczestników kopania złota w Treblince. Przechwyconych karano chłostą"56. To znaczy jedni kopali, a drudzy na nich napadali, żeby im zabrać, co wykopali?

Miesiąc później, 11 marca 1946 r., H. Krajewski, starosta powiatowy w Węgrowie ${ }^{57}$, „b[ardzo] pilnie” zawiadamiał miejscową Komendę Powiatową o plądrowaniu treblińskich grobów:

${ }^{51}$ Archiwum Państwowe w Warszawie Oddział w Milanówku (dalej AP Warszawa), Urząd Wojewódzki Warszawski 1944-1950, Wydział Społeczno-Polityczny, Profanacja Treblinki, 259, k. 1-2.

${ }^{52}$ Starostą powiatowym w tym okresie był Stanisław Pękalski, a 26 grudnia stanowisko to powierzono Grzegorzowi Radomskiemu, zajmował je do $1948 \mathrm{r}$.

${ }^{53}$ AP Warszawa, Urząd Wojewódzki Warszawski 1944-1950, Wydział Społeczno-Polityczny, Profanacja Treblinki, 259, k. 4.

${ }^{54}$ Żochy leżą około $15 \mathrm{~km}$ od Treblinki.

${ }^{55}$ AIPN, 00495/79, Meldunki specjalne nadsyłane z KP MO w Sokołowie Podlaskim do Komendy Milicji Obywatelskiej Województwa Warszawskiego, KP MO w Sokołowie Podlaskim do Komendy Głównej MO w Warszawie, 16 II 1946 r., k. 14.

${ }^{56}$ Według „Kroniki 6 Brygady Wileńskiej” oddziałem, który prowadził akcje przeciwko kopaczom, był oddział „Wiktora”-„Młota”. Opisują to Kazimierz Krajewski i Tomasz Łabuszewski w: „Łupaszka”, „Młot”, „Huzar”. Działalność 5 i 6 Brygady Wileńskiej AK (1944-1952), Warszawa: IPN, 2002. Oddział „Wiktora”-„Młota” miał przebywać w rejonie Treblinki od 2 do 6 II 1946 r. 4 II 1946 r. udał się do wsi Wólka Okrąglik „na ekspedycję karną przeciw poszukiwaczom złota w Treblince". Do zatrzymania kopaczy doszło w nocy z 5 na 6 II 1946 r., a kopiących ukarano batami. Warto jednak zwrócić uwagę, że w przeciwieństwie do tej narracji, zgodnie z którą oddziały podziemia zbrojnego próbowały pełnić funkcje porządkowe, Paweł Reszka zauważa, że mógł być to również element „kontrybucji na rzecz oddziałów”. Kwestia ta wymaga dalszych kwerend (Reszka, Płuczki..., s. 210).

${ }^{57}$ Jak wspominałem, tereny obozu Treblinki II znajdowały się częściowo w gminie Prostyń, która przynależała do powiatu węgrowskiego. Zdecydowanie większa jego część leżała w gminie Kosów Lacki, w granicach powiatu sokołowskiego. 
Przesyłając w załączeniu telegram Starosty Powiatowego w Ostrowi Mazowieckiej z dn. 6 marca 1946 roku donoszący o wysadzaniu przez okoliczną ludność grobów straconych w Treblince i plądrowaniu takowych - proszę o ni ezwłoczne [w oryginale podkreślone - M.K.] zajęcie się tą sprawą z Powiatowym Urzędem Bezpieczeństwa Publicznego w Węgrowie ${ }^{58}$.

Sprawa musiała być wyjątkowo bulwersująca. 15 marca kolejne pismo do starosty w Węgrowie wysłał Warszawski Urząd Wojewódzki. Ten sam, który 6 lutego twierdził, że problem nie istnieje. „Starostwo Ostrowskie donosi, że w Treblince miejscowa ludność wraz z żołnierzami wygrzebuje groby straconych i szuka w zwłokach złota i brylantów, dokonuje tego przez wysadzanie grobów materiałami wybuchowymi" ${ }^{59}$ - pisał w alarmistycznym tonie, dodając, że gdyby informacje te się potwierdziły, „prosi o zabezpieczenie cmentarzyska od profanacji".

Starosta węgrowski ponaglał milicję do działania, pytając ją o rezultaty prac w następnym piśmie z 27 marca. Mundurowi nie mieli wyjścia i ruszyli w teren. 17 kwietnia otrzymał od nich satysfakcjonujący meldunek, który przesłał dalej do Warszawy.

W porozumieniu z M.O. Sokołów, ponieważ większa część tego terenu należy do pow. Sokołów, urządzono kilka akcji, w wyniku których zostało zatrzymanych około 70 osób, z których część odesłano do prokuratora. Ostatni wypad M.O. Węgrów nie dał żadnych wyników, i jak ustalono, plądrowanie ustało ${ }^{60}$.

Część schwytanych w czasie tych akcji znalazła się prawdopodobnie w milicyjnym areszcie w Sokołowie Podlaskim. Jak wynika ze sprawozdania z przełomu marca i kwietnia 1946 r. „M.O. posiada zatrzymanych 23 osoby, w tym 12 osób zatrzymanych w Treblince za wykopywanie i rozkopywanie mogił wspólnych, które są pozostałością po okupantach, zatrzymani szukający złota, brylantów, złotych zębów oczekują decyzji Prokuratora"61. W powyższej wymianie pism zastanawiający jest wątek dotyczący meldunku starosty z Ostrowi Mazowieckiej, leżącej $20 \mathrm{~km}$ od Treblinki, za Bugiem, gdyż teren obozu nie podlegał mu w żaden sposób. Dlaczego sprawą tą zajmował się akurat starosta tego powiatu? Możliwe, że było to powiązane z jednostką wojskową z Ostrowi używaną podczas obław ${ }^{62}$.

${ }^{58}$ AP Warszawa, Urząd Wojewódzki Warszawski 1944-1950, Wydział Społeczno-Polityczny, 72/500/511, Starosta Powiatowy Węgrowski do Komendy Powiatowej MO w Węgrowie, k. 25.

${ }^{59}$ Ibidem, k. 24.

${ }^{60}$ Ibidem, k. 22.

${ }^{61}$ AIPN, 0446/9, Raport dekadowy PUBP Sokołów Podlaski 1946, Raport dekadowy sprawozdawczy za okres od 28 III do 8 IV 1946 r., k. 46.

${ }^{62}$ W latach 1945-1946 w Ostrowi stacjonowały pododdziały 3 Berlińskiego Pułku Piechoty oraz kolumna samochodowa 1 Pułku Samochodowego. W artykule Piotra Głuchowskiego i Marcina Kowalskiego (Gorqczka złota $w$ Treblince) pojawia się informacja, że żołnierze z tej 
Jak wspominałem, w pierwszych latach po wojnie władze cierpiały na brak wszystkiego. „Stacjonuje u nas jedna bateria w sile czterdziestu ludzi, z którymi nie można współpracować, którzy to okazują swoją tchórzliwość w porze nocnej, oficerowie tłumaczą się tym, że nie są obstrzelani i nigdy w boju nie byli" - meldował w maju 1946 r. Roman Czubak, szef PUBP w Sokołowie Podlaskim ${ }^{63}$. W tym samym miesiącu donosił, że stan personalny jego placówki jest fatalny. Składał się on z zaledwie 21 dyspozycyjnych osób ${ }^{64}$. Dla porównania, gdy 14 kwietnia 1946 r. prawdopodobnie grupa „Młota”65 zaatakowała wieś Wyrozęby (pow. Sokołów), według raportu specjalnego liczyła 100 osób:

Wszyscy ubrani po wojskowemu, uzbrojeni w broń maszynową, a mianowicie RKM, dyktyrowy ${ }^{66} \mathrm{i}$ automaty, pistolety, granaty różnego rodzaju oraz przeciwpancerne. Po opanowaniu wsi w pierwszym rzędzie udali się na posterunek, gdzie rozbroili dwóch milicjantów [...], udali się następnie do Spółdzielni „Czuwaj” [...] i tu zrabowali wszystkie towary i gotówkę na łączną sumę około 350 tys. zł. [...] Towar załadowali na furmanki, których mieli ze sobą $7^{67}$.

Tymczasem po stronie władz problemem były nie tylko liczebność czy uzbrojenie, ale nawet zwykła komunikacja. W czerwcu 1946 r. jednostka wojskowa $\mathrm{w}$ sile 40 ludzi po prostu wyjechała z Sokołowa, nie informując o tym nikogo ${ }^{68}$.

Szef placówki UB miał do niej inne poważne zastrzeżenia. Kiedy próbował ją wysłać w teren po otrzymaniu informacji o zarekwirowaniu trzech samochodów ciężarowych przez bliżej nieznaną grupę, jej reakcja była następująca: „Powiadomiona jednostka nasza nie wyjechała, tłumacząc się, pomimo że [sic!] ma-

jednostki uczestniczyli w obławie zaraz po wizycie komisji sędziego Łukaszkiewicza, ale wizytę komisji datują błędnie na rok 1947. Tymczasem odbyła się ona w listopadzie $1945 \mathrm{r}$. Piszą: „Obławę zorganizowano profesjonalnie - część terenu zaminowano, by uniemożliwić ucieczkę kopiącym i ich ochronie. Tyraliera wojskowych nadeszła z drugiej strony. Trzech okrążonych wyleciało w powietrze na minach, kilkadziesiąt kobiet i mężczyzn zatrzymano". Okoliczności można powiązać z cytowanym wcześniej meldunkiem komendanta MO z Kosowa Lackiego z 29 IX 1945 r., który także raportował o stosowaniu min i ofiarach. Obławy z użyciem wojska, o których piszą Głuchowski i Kowalski, przeprowadzano zatem prawdopodobnie między końcem sierpnia a końcem września 1945 r. Publikowane przez nich zdjęcie ludności zatrzymanej przez żołnierzy, które dziennikarze odnaleźli w 2008 r., może pochodzić właśnie z tego okresu. Wskazywałby na to widoczny m.in. lekki ubiór sfotografowanych postaci, charakterystyczny dla późnego lata w tym regionie.

${ }^{63}$ AIPN, 0446/9, Raport dekadowy sprawozdawczy za okres od 28 III do 8 IV 1946 r., k. 59.

${ }^{64}$ AIPN, 0446/9, Raport sprawozdawczo-dekadowy od 8 do 18 V 1946 r., k. 65.

${ }^{65}$ Władysław Łukasik ps. „Młot” (1906-1949), jeden z najbardziej znanych przywódców zbrojnego podziemia w powiecie sokołowskim.

${ }^{66}$ Ręczne karabiny maszynowe Diegtiariowa.

${ }^{67}$ AIPN, 0446/9, Raport specjalny PUBP w Sokołowie Podlaskim do szefa WUBP w Warszawie, k. 68.

${ }^{68}$ Ibidem, Raport sprawozdawczo-dekadowy zakres od 28 V do 8 VI 1946 r., k. 81. 
szyna jest niesprawna, choć rano tego dnia jeździli dość długo wokół miasta”69. Patrolowanie terenu, gdzie funkcjonowało silne podziemie zbrojne, bez odpowiedniego przygotowania było ryzykowne. Lokalna władza zmagała się z wieloma trudnościami, nie miała poparcia społecznego ${ }^{70}$, a ludność klepała biedę.

Miasto na kartki żywnościowe nie otrzymuje dostatecznych artykułów pierwszej potrzeby, za miesiąc kwiecień i do chwili obecnej nie otrzymali mięsa, nie otrzymują chleba, wydano po $1 / 4 \mathrm{~kg}$ cukru na osobę, po kawałku mydła i deko herbaty, na dziecinne kartki po litrze soku [...]. W mieście wskutek tego jest pomiędzy ludnością rozgoryczenie i niezadowolenie ${ }^{71}$.

W terenie zaś wciąż ginęli ludzie, czy to z powodów politycznych, czy kryminalnych, i pod względem statystycznym rok 1946 ogółem był gorszy niż $1945^{72}$.

W takich warunkach stanowisko milicji z Węgrowa, że plądrowanie ustało, było raczej życzeniem niż stwierdzeniem faktu. 25 maja 1946 r. Powiatowa Rada Narodowa w Sokołowie Podlaskim - „wobec profanowania zbiorowych mogił w b[yłym] obozie w Treblince” - omawiała z kolei projekt uchwały mającej dać administracyjną podstawę karania „zwyrodniałych, w szakali obracających się ludzi, którzy w poszukiwaniu złota rozkopują mogiły"73. Projekt zakładał:

1) ludność zarejestrowaną w rozgrzebywaniu mogił, którzy zrobili majątek, obciążyć specjalnym podatkiem. 2) Wyeliminować ich ze wszystkich ulg i pomocy materialnych, jakie świadczy na rzecz obywateli Państwo. 3) Podciągnięcie okolicznych mieszkańców do świadczeń szarwarkowych bezpłatnie dla szybszego regulowania i wykonania prac z regulacją rzeki Kosówka ${ }^{74}$.

Powodem wniesienia tego projektu było, jak czytamy dalej, rozczarowanie postawą organów ścigania. „Niejednokrotne i masowe aresztowania, oddanie sprawy pod sąd Prokuratora. Wynik. Grzywna 500 zł, co dało impuls i powód do tym większego i masowszego rozkopywania grobów". I jeszcze jedno wyjaśnienie. „Niejednokrotnie były obławy w tej okolicy na rozkopujących, padały strzały, z tamtej strony, jak i ze strony M.O. i U.B.P. były ofiary, to jednak wszystko nie wpłynęło na zahamowanie profanacji grobów, gdyż żądza zysku była większa"75.

\footnotetext{
${ }^{69}$ Ibidem, k. 76.

${ }^{70} \mathrm{Na}$ przykład „Ludność powiatu sokołowskiego na terenie oraz nastrój jest wrogi” (ibidem).

${ }^{71}$ AIPN, 0446/9, Raport sprawozdawczo-dekadowy za okres od 8 V do 18 V 1946 r., k. 60.

${ }^{72}$ Liczba napadów na instytucje państwowe i partyjne: 1945 - 25, 1946 - 51; zabójstwa funkcjonariuszy UB, MO PPR i innych - 13 do 30; terror stosowany przeciwko ludności cywilnej - 13 do 66, za to liczba aresztowanych członków grup przeciwrządowych zmniejszyła się z 773 do 208 (AIPN, 0446/9, k. 255-256).

${ }^{73}$ Archiwum Państwowe w Siedlach (dalej AP Siedlce), Powiatowa Rada Narodowa w Sokołowie Podlaskim 1944-1950, 62, Protokoły posiedzeń PRN, Protokół numer X posiedzenia Powiatowej Rady Narodowej w Sokołowie Podlaskim z 25 V 1946 r., k. 9.

${ }^{74}$ Ibidem, k. 10.

${ }^{75}$ Ibidem.
} 
Projekt uchwały wysłano do Wojewódzkiej Rady Narodowej celem zatwierdzenia, ale nie udało się odnaleźć jego dalszych losów. Pisma sokołowskiej PRN można odczytywać wręcz jako próbę wywarcia presji, by skończyć z procederem. Rozpaczliwe poszukiwanie narzędzia do wymierzania kary nie wskazuje, że był to problem kilku osób. Roboty szarwarkowe jako sankcję prawdopodobnie stosowano już wcześniej. Robotnicy pracujący dla sędziego Łukaszkiewicza jesienią 1945 r., tak dobrze zorientowani gdzie i co można wykopać na terenie obozu, wykonywali właśnie szarwark.

Tymczasem 26 sierpnia 1946 r. wojewoda warszawski ponownie zapytał starostę w Węgrowie, jak wygląda sytuacja.

Obóz w Treblince w obecnym czasie stanowi ciemną plamę na terenie naszego województwa. Według otrzymywanych wiadomości, jest on żerowiskiem „hien” cmentarnych, które nocami poszukują kosztowności pozostałych po wymordowanych. Proszę o możliwie szybkie sprawozdanie ${ }^{76}$.

Odpowiedź nadeszła dopiero 12 października. W pierwszym zdaniu nowy starosta węgrowski zwrócił przełożonemu delikatnie uwagę, że „większa część terenu i cmentarza [...] leży na terenie gminy Kosów, pow. Sokołowskiego", wyraźnie nie poczuwając się do odpowiedzialności za prowadzenie tej sprawy. Dodał następnie, że terenem po byłym obozie rzeczywiście nikt się nie zajmuje: „Teren [...] nie jest ogrodzony i groby nie są zabezpieczone, żaden urząd ani instytucja dotychczas sprawą obozu nie zainteresowała się"77. Jedynym śladem jakiejkolwiek interwencji jego poprzednika w tej sprawie były przywoływane już obławy z kwietnia 1946 r., kiedy to zatrzymano 70 osób.

W połowie września 1946 r. żołnierze Wojsk Bezpieczeństwa Wewnętrznego, zatrzymali w Warszawie Dominika K., mieszkańca Kiełczewa, wsi położonej 6 km od Treblinki. W czasie rewizji okazało się, że miał przy sobie 60 dolarów amerykańskich w złocie i 39 tys. $\mathrm{zt}^{78} .15$ września podczas pierwszego przesłuchania na pytanie: „Skąd mieliście dolary, które przy Was znaleźli?”, odpowiedział:

W miesiącu wrześniu znalazłem przy trupach w Treblince „brylanta” w szmatach, którego spieniężyłem za 200000 złotych w sklepie w Warszawie, później we wsi Treblinka za 150000 kupiłem 60 dolarów w złocie, od ludzi,

${ }^{76}$ AP Warszawa, Urząd Wojewódzki Warszawski 1944-1950, Wydział Społeczno-Polityczny, 72/500/511, Wojewoda warszawski do Starostwa Powiatowego w Węgrowie, 26 VIII 1946 r., k. 7.

${ }^{77}$ Ibidem, k. 6.

${ }^{78}$ W 1946 r. za 100 zł można było zakupić 38,3 dolarów, a kwintal żyta kosztował 1544 zł (Mirosław Kłusek, Zasady przeliczania nakładów finansowych poniesionych w latach 19452010 przez Muzeum Pałacu w Wilanowie i jego poprzednika prawnego, „Annales. Etyka w życiu gospodarczym" 2014, t. 17, nr 2, tab. 4, s. 107). 
którzy rozkopują trupów i znajdują różne wartościowe przedmioty. Zostało mi 50 000, z których 10000 zł wydałem na swoje potrzeby ${ }^{79}$.

W toku postępowania przygotowawczego K. był przesłuchiwany łącznie cztery razy. Zatrzymany był 25-letnim mężczyzną, żonatym, ojcem 10-miesięcznego dziecka, katolikiem, rolnikiem ze stanem posiadania 4,5 morgi gruntu, z ukończonymi sześcioma klasami szkoły podstawowej. Do końca stycznia $1946 \mathrm{r}$. służył w Straży Ochrony w Małkini. Później pozostawał bez pracy.

W Treblince byłem kilkanaście razy, zanim znalazłem wyżej wymienionego „brylanta”. Chodziłem tam w nadziei, że znajdę coś wartościowego, razem z innymi mieszkańcami mojej wioski, czyli moimi sąsiadami. W miejscu, gdzie chodziliśmy kopać, jest dużo trupów, w których znajdują się rzeczy wartościowe ${ }^{80}$.

Kilka dni później dodał: „z naszych okolic i ludzie przyjezdni zawsze poszukują złota i kosztowności na terenie b[yłego] obozu"81. Przed sędzią śledczym dopowiedział jeszcze: „Grzebaliśmy się w gruzach po spalonych magazynach, w których w swoim czasie Niemcy magazynowali odzież zatrzymanych w obozie"82.

Niezależnie od tego, gdzie konkretnie K. znalazł swój brylant, w Treblince pojawił się łącznie kilkanaście razy w roku - z sąsiadami lub innymi mieszkańcami wioski oraz ludzi przyjezdnymi. W zeznaniu przed śledczym z Wydziału Kryminalnego MO twierdził z kolei, że do obozu chodził „raczej często”"83. W zeznaniu potwierdził też doniesienie starosty ostrowskiego o używaniu materiałów wybuchowych na terenie poobozowym: „Żołnierze radzieccy także z nami chodzili i szukali. Te miejsca, gdzie spodziewali się znaleźć kosztowności, nawet wysadzali" ${ }^{\prime 2}$.

Można raczej założyć, że to nowe zajęcie było stałe. Być może łączyło się z innymi profitami. Świeżo upieczony ojciec pracę stracił przecież w styczniu, w Warszawie zatrzymano go we wrześniu, a o innym zarobku nie wspominał. Gdy znalazł brylant, pierwszą osobą, której go pokazał, była żona. Później zaś pojechał do znajomego ze wsi Poniatowo, by potwierdzić prawdziwość znaleziska. Można się zastanawiać, skąd na podlaskiej wsi w 1946 r. znalazł się znawca brylantów.

${ }^{79}$ Ibidem.

${ }^{80}$ AP Siedlce, Sąd Okręgowy, 580, Protokół przesłuchania 16 IX 1946 r., k. 6. Pierwsze przesłuchania prowadził Wydział Informacji Wojsk Bezpieczeństwa Publicznego woj. warszawskiego, a 27 IX 1946 r. Kucharczyka przekazano do dyspozycji Wydziału Śledczego Komendy Głównej MO.

${ }^{81}$ Ibidem, Protokół przesłuchania podejrzanego 28 IX 1946 r., k. 8. To przesłuchanie prowadził Wydział Kryminalny Służby Śledczej Komendy MO miasta stołecznego Warszawy.

${ }^{82}$ Ibidem, k. 12. Przesłuchanie toczyło się przed sędzią śledczym I rejonu Sądu Okręgowego w Warszawie. W czasie tego przesłuchania Kucharczyk przyznał się do winy.

${ }^{83}$ Ibidem, k. 8.

${ }^{84}$ Ibidem. 
Tenże ekspert, pojawiający się w śledztwie później - Stanisław S., katolik, rolnik, lat 23, jak się okazało, był pośrednikiem. „Pojechałem z ww. kolegą do Warszawy i sprzedałem ten brylant za 200000 zł. Po powrocie do domu tego samego dnia poszedłem z kolegą do Treblinki i kupiłem 3 monety złote, 20 dolarów, za które zapłaciłem $150000 \mathrm{zł}^{\prime \prime 85}$. Ponownie musi paść pytanie, jak to możliwe, by w 1946 r. w takim miejscu można było kupić trzy złote dwudziestodolarówki.

Sędziego śledczego chyba tknęła jakaś nieoczywistość tych zeznań. 23 listopada 1946 r. postanowił dopytać K. o transakcję. Ten początkowo zasłaniał się niepamięcią, by w końcu wyznać: „W czasie tym ci, co mieli dolary do sprzedania, oddawali je kupcom z Warszawy czy z Białegostoku po 45-46 tysięcy za 20-dolarówkę, a ja [...] musiałem płacić po $50000 \mathrm{zł}$, bo woleli kupcom sprzedawać" ${ }^{\prime \prime 6}$. Jak widać, K. był zorientowany w cenach, poza tym nie wysilał się specjalnie, by trafić do siatki pośredników, działających przecież nielegalnie w okolicy obozu, i z tego, co widać, obracających znacznymi kwotami. Sam Stanisław S., jak wynika z akt, za udział w sprzedaży brylantu dostał 2000 zł. W innych aktach odnalazłem jeszcze inny ślad potwierdzający dziwne interesy na terenie obozu. W październiku $1946 \mathrm{r}$. za nielegalny handel złotem zatrzymano tam Stanisławę S. Oprócz suchego komunikatu w sprawozdaniu PUBP nic więcej nie wiemy o tym przypadku ${ }^{87}$.

Tymczasem sprawę znalazcy brylantu oddelegowano z Warszawy do Siedlec, a tam 4 grudnia 1946 r. prokurator, który za nią odpowiadał, zarekomendował przełożonemu przeprowadzenie jej w drodze postępowania zwyczajnego: „Nie należy bowiem oczekiwać, szczególnie surowej kary dla podejrzanego"88. Trudno powiedzieć, dlaczego prokurator założył taki rezultat. Zresztą nie tylko to budzi w tej sprawie wątpliwości. Otóż Kucharczyka oskarżono ostatecznie z art. 43 par. 1. Dekretu o przestępstwach szczególnie niebezpiecznych w okresie odbudowy Państwa z 13 czerwca $1946 \mathrm{r}^{89}$, który penalizował... „przywłaszczanie cudzego mienia ruchomego pozbawionego należytej ochrony w związku z wojną". W odrębnej sprawie, która się nie zachowała, ale wspomina o niej akt oskarżenia, Dominikowi K. postawiono zarzut z art. 6 dekretu z 22 kwietnia 1936 r. ${ }^{90}$

${ }^{85}$ Ibidem.

${ }^{86}$ AP Siedlce, Sąd Okręgowy, 580, Protokół przesłuchania podejrzanego 23 XI 1946 r., k. 20. Przesłuchanie prowadził sędzia śledczy I rejonu Sądu Okręgowego w Warszawie.

${ }^{87}$ AIPN, 0446/9, Raport dekadowy sprawozdawczy za okres od 8 do 18 X 1946 r., k. 218: „W okresie sprawozdawczym dokonano następujących aresztowań - S[...] Stanisława zatrzymana za nielegalny handel złotem na terenie obozu w Treblince”. Podobne typy „handlu” i specjaliści od brylantów pojawili się po wojnie we wszystkich okolicach byłych obozów śmierci.

${ }^{88}$ AP Siedlce, Sąd Okręgowy, 580, k. 24.

${ }^{89}$ Dz.U. RP 1946, nr 30, poz. 192, Dekret z dnia 13 czerwca 1946 r. o przestępstwach szczególnie niebezpiecznych w okresie odbudowy Państwa.

${ }^{90}$ Dz.U. 1936, nr 32, poz. 249, Dekret Prezydenta Rzeczypospolitej z dnia 26 kwietnia 1936 r. w sprawie obrotu pieniężnego z zagranicą oraz obrotu zagranicznemi i krajowemi środkami płatniczemi. 
Ten z kolei dotyczył zakazu handlu złotem - za jego złamanie groziła kara więzienia do lat pięciu i grzywna do 200 tys. zł. W tym czasie obowiązywał już w Polsce tzw. mały kodeks karny, który jednoznacznie w art. 26 wskazywał, że znieważenie lub uszkodzenie zwłok [...] osoby, która padła ofiarą zbrodniczych działań faszystowskich, groziło do 10 lat więzienia ${ }^{91}$. Dlaczego K. nie oskarżono $\mathrm{z}$ tego paragrafu?

Nie wiemy, jak ostatecznie zakończyła się sprawa mieszkańca Kiełczewa. Ostatnie pismo w jego teczce pochodzi z 27 stycznia $1947 \mathrm{r}$. i dotyczy zapytania o karalność. Z 26 stycznia pochodzi natomiast list do żony wysłany z więzienia w Mokotowie. Pisał w nim:

Zosiu proszę cię bardzo nie zapominaj o mie, a tem bardziej o paczkach dla mie. Kochana, chowaj dobrze małego Bogdana, ażeby jak najszybciej rósł. Żono ja sprawy jeszcze nie miałem i jeszcze nie wiem, kiedy ją będę miał. Kochana Żono, bądź bardzo wdzięczną dla brata Janka i Halinki, że nie szkodują czasu nad podaniem paczek dla mnie. Kończę list, zostawaj zdrowa z małym Bogdanem $^{92}$.

\section{„Nikt z tych ludzi słowa nie powiedział”}

Rok 1947 przyniósł nadzieję na zakończenie profanowania cmentarzyska. 1 i 2 kwietnia wizytowali je przedstawiciele CŻKH z sędzią Łukaszkiewiczem ${ }^{93}$, w efekcie czego 12 maja Prezydium Centralnego Komitetu Żydów w Polsce omawiało zabezpieczenie terenu. Padł również pomysł budowy muzeum ${ }^{94} .19$ maja Hersz Smolar ${ }^{95}$ na posiedzeniu Prezydium CKŻP zaproponował, by cały obszar ogrodzić drutem, a ziemię zalać betonem ${ }^{96}$.

Tymczasem proceder trwał nadal. 18 kwietnia 1947 r. Oddział Drogowy Dyrekcji Okręgowej Kolei Państwowych w Małkini zawiadamiał Starostwo Powiatowe w Węgrowie, że „okoliczna ludność zamieszkująca w pobliżu bocznicy prowadzącej do żwirowni Treblinka, ubiegająca się za poszukiwaniem kosztowności, rozkopuje tor tej bocznicy obok b[yłego] obozu niemieckiego, gdzie byli traceni ludzie". Żwirownia, o której mowa w piśmie, była w czasie wojny częścią obozu pracy Treblinka I. Po wojnie nadal eksploatowano jej zasoby.

${ }^{91}$ Dz.U. 1946, nr 30, poz. 192.

${ }^{92}$ AP Siedlce, Sąd Okręgowy, 580, b.p. W cytacie zachowano oryginalną pisownię łącznie $\mathrm{z}$ interpunkcją.

${ }^{93}$ AŻIH, Oględziny obozu zagłady w Treblince, „Biuletyn ŻAP”, 15 IV 1947, nr 34 (282), s. 3.

${ }^{94}$ AŻ̇H, Komisje Żydowskie na terenach b. obozów śmierci, „Biuletyn ŻAP”, 1 V 1947, nr 45 (293), s. 1.

${ }^{95}$ Hersz (Grzegorz) Smolar (1905-1993), działacz społeczny, komunista, od 1948 członek PZPR. W latach 1950-1962 stał na czele Towarzystwa Społeczno-Kulturalnego Żydów w Polsce. Długoletni redaktor naczelny „Fołks-Sztyme”. Odsunięty od pracy w wyniku kampanii antysemickiej w 1968 r. Wyjechał z Polski; osiadł w Izraelu.

${ }^{96}$ AŻIH, CKŻP - Prezydium, 303/I/21, Protokół 46 z 19 V 1947 r., s. 31. 
Rozkopywanie bocznicy musiało być dość zaawansowane, skoro zdaniem kolejarzy zagrażało bezpieczeństwu ruchu pociągów. Na samym końcu dodano, że „ukrócenie powyższego postępowania jest również konieczne i ze względów moralnych" ${ }^{\prime \prime}$.

18 czerwca 1947 r., po trzech latach od ucieczki niemieckich wartowników $\mathrm{z}$ „gospodarstwa”, do Treblinki dowieziono aż dziesięcioma samochodami osobowymi pierwszą dużą delegację, z mocną ochroną wojskową. Znajdowali się w niej posłowie, oficjele z warszawskiego Urzędu Wojewódzkiego, przedstawiciele Centralnego Komitetu Żydów w Polsce, władz oraz organizacji społecznych. Był wśród nich również Chil Kirszenbaum, Żyd ocalały z Zagłady.

Gdy przyjechałem na miejsce, nie uwierzyłem własnym oczom. W dołach, gdzie leżeli zabici, siedzieli okoliczni chłopi ze specjalnie przystosowanymi grabiami [...]. Wstrząsający widok obozu zagłady odebrał wszystkim chęć do rozmowy. Ludzie patrzeli na siebie i oczy same wszystko wyjaśniły. Podszedł do mnie miejscowy chłop, trzymając w ręku jakąś tabliczkę z napisem hebrajskim, żeby to od niego kupić ${ }^{98}$.

Dla przybyłych ten widok musiał być szokiem. „Gazeta Ludowa” zatytułowała swoją relację wymownie: Treblinka! Straszny ten wyraz przypomniał się Polsce, a jej dziennikarz pisał:

Teren obozu po dziś dzień jest niezabezpieczony i przedstawia niesamowity widok. Na przestrzeni kilku hektarów rozrzucone są kości, czaszki, resztki włosów i ubrań ofiar. W niektórych miejscach szczątki pomordowanych tworzą olbrzymie pryzmy kości i czaszek ${ }^{99}$.

Kirszenbaum wykonał kilka fotografii terenu oraz „grabi”, o których wspominał w relacji (w rzeczywistości były to czteropalczaste widły, zakrzywione ku górze, przystosowane do głębokiego przeczesywania piasku), a także licznych gapiów przybyłych $\mathrm{w}$ trakcie wizytacji”. Nikt z tych ludzi słowa nie powiedział. Wszyscy byli zjednoczeni w milczeniu"100.

Ta wizyta spowodowała zmianę, przynajmniej teoretycznie. Wojewoda przyznał 300 tys. zł na "natychmiastowe prace ogrodzeniowe” oraz barak służący jako wartownia. Efektem wyjazdu było też powołanie Komitetu, który miał się zająć zbieraniem funduszy potrzebnych do uporządkowania terenu i upamiętnienia

${ }^{97}$ AP Siedlce, Gmina Prostyń, 100, Pismo Oddziału Drogowego DOKP w Małkini z 18 IV 1947 r., k. 85.

${ }^{98}$ Chil Kirszenbaum, Moje notatki z piekła. Bestialskie wymordowanie Żydów w Mińsku Mazowieckim, Warszawa: Przedsiębiorstwo Wydawniczo-Handlowe „Graf”, 2006, s. 245. Dziękuję Alinie Skibińskiej na zwrócenie uwagi na tę relację.

${ }^{99}$ Treblinka! Straszny ten wyraz przypomniał się Polsce, „Gazeta Ludowa”, 19 VI 1947, nr 166, s. 2.

${ }^{100}$ Kirszenbaum, Moje notatki z piekła..., s. 249. 
pomordowanych ${ }^{101}$. W praktyce zmianę trudno było zauważyć. 17 lipca kolejna delegacja, tym razem z ramienia CKŻP, „w wyniku stwierdzenia przez delegację stanu terenu dawnego obozu" postanowiła wziąć sprawy w swoje ręce i zająć się organizacją zabezpieczenia ${ }^{102}$. Potwierdzenie wybudowania prowizorycznego płotu pojawiło się w depeszy Żydowskiej Agencji Prasowej dopiero 25 września z $1947 \mathrm{r}^{103}$ Chciałoby się rzec - nareszcie. Dość mgliste były również informacje o ochronie obozu. W informacji ŻAP mówiono o delegowanej tam jednostce wojskowej, ale niewiele o niej wiemy. Na miejscu funkcjonowała przynajmniej od lipca. Tak wynika z krótkiej notki o wywołaniu zajścia przez „Dowódcę ochrony b[yłego] obozu koncentracyjnego w Treblince por. Cialunia" z Zarządem Gminy Prostyń w dniu 21 lipca 1947 r." ${ }^{\prime 104}$. Niestety, w dokumentach nie podano, na czym polegało to zajście. Z jesiennych informacji ŻAP można jednak wnioskować, że działania władz i CKŻP powstrzymały masową profanację cmentarzyska albo przynajmniej ją utrudniły.

W tym miejscu trzeba wspomnieć o kolejnym ważnym świadku, który był w Treblince w 1947 r. Mowa o Mordechaju Caninie, żydowskim dziennikarzu z brytyjskim paszportem. Canin, urodzony w 1906 r. w Sokołowie Podlaskim ${ }^{105}$, w drugiej połowie 1947 r. przemierzał Polskę, opisując rzeczywistość dawnych żydowskich miasteczek ${ }^{106}$. Pisał wówczas dla nowojorskiego „Forwerts”107. Nie wiemy, kiedy dokładnie pojawił się w omawianym rejonie, ale był tam dwukrotnie - pierwszy raz na terenie samego obozu i we wsi Wólka Okrąglik, a drugi raz w Kosowie Lackim ${ }^{108}$. Pisał, wstrząśnięty:

${ }^{101}$ AŻIH, O opiekę nad terenem obozu w Treblince, „Biuletyn ŻAP”, 20 VI 1947, nr 58 (306), s.3-4.

${ }^{102}$ AŻıH, Przedstawiciele społeczeństwa żydowskiego na terenie byłego obozu zagłady w Treblince, „Biuletyn ŻAP”, 19 VII 1947, nr 69 (317), s. 2.

${ }^{103}$ AŻ̇H, Zabezpieczenie dawnego obozu w Treblince, „Biuletyn ŻAP”, 25 IX 1947, nr 95 (343), s. 4.

${ }^{104}$ AP Siedlce, Gmina Prostyń, 62/261, Sprawozdanie sytuacyjne wójta gminy Prostyń, pow. węgrowskiego, za lipiec 1947 r., k. 42.

${ }^{105}$ Sokołów Podlaski leży około $30 \mathrm{~km}$ od terenu obozu.

${ }^{106}$ Mordechaj Canin, Przez ruiny i zgliszcza. Podróż po stu zgładzonych gminach żydowskich w Polsce, tłum. i oprac. Monika Adamczyk-Garbowska, Warszawa: Nisza i ŻIH, 2018.

107 „Forwerts” - jedna z najbardziej rozpoznawalnych gazet w języku jidysz, wydawana w Nowym Jorku, propagująca świecki nurt w diasporze żydowskiej, opowiadający się za socjalizmem i demokracją. Osiągała olbrzymie nakłady: na początku lat trzydziestych - 275 tys., w 1939 r. -170 tys., w 1951 r. -80 tys. dziennie.

${ }^{108}$ Artykuł o Treblince Lublin, Bialistok un Treblinke (Lublin, Białystok i Treblinka) ukazał się w „Forwerts” 28 X 1947 r. na stronie 2. Na terenie obozu Canin musiał być wcześniej. Z relacji wynika, że w okolicy obozu był dwa razy w jakimś odstępstwie czasu. Za pierwszym razem do Treblinki przyjechał pociągiem, za drugim dotarł do Kosowa furmanką, po przeprawie przez Bug. W relacji o Treblince nie wspomina nic o płocie czy ochronie. Prawdopodobnie więc trafił tam w okolicy czerwca, lipca $1947 \mathrm{r}$. 


\section{Studia}

Bliżej wschodniej granicy obozu - morze ludzkich kości i czaszek, kończyny i żebra, tysiące, dziesiątki tysięcy, stąpasz po ludzkich kościach. Wyżej, po stronie północnej, tam, gdzie zakopano zagazowane ciała, odkrywam dół głębokości dwudziestu metrów. To nie dół, to otchłań, otchłań wypełniona głowami i kawałkami ciał. - [...] Setki czaszek mają wyłamane szczęki - to dowód, że ograbiono je ze złotych zębów. I widzę: ze stosu kości wystaje dziecięca stópka, w buciku ${ }^{109}$, buciku trzy-, czteroletniego dziecka. Podnoszę maleńką czaszkę i widzę nie czaszkę, ale żywe żydowskie dziecko ${ }^{110}$.

Mordechaj Canin, przybywszy do Treblinki, przedstawił się jako angielski dziennikarz. Tak „ważnego gościa” miejscowy zawiadowca stacji zapoznał więc z sołtysem wsi Wólka Okrąglik. To właśnie sołtys zawiózł go do byłego obozu.

Po drodze przejeżdżaliśmy przez wieś o nazwie Poniatowo. Wszystkie chałupy we wsi były nowe. Pytam chłopa, czy to nowa wieś. Odpowiada, że tylko chałupy są nowe. [...] Odbudowały się dzięki obozowi w Treblince. Kiedy weszli Rosjanie, a Ukraińcy uciekli z kolonii, chłopi masowo ruszyli do byłego obozu i zaczęli przekopywać ziemię. [...] Nawet z dalekich wsi przyjeżdżali tutaj szukać i starczyło dla wszystkich... ${ }^{111}$

Sołtys wymienił też inne spalone wsie, które odbudowały się „dzięki” obozowi - Wólkę, Prostyń i Treblinkę ${ }^{112}$.

Kiedy dziennikarz przyjechał w okolice obozu powtórnie, tym razem jego celem był Kosów Lacki, a tak naprawdę chciał sprawdzić prawdopodobieństwo plotki o potyczce między chłopami z różnych wsi, którzy mieli konkurować o pierwszeństwo w kopaniu ${ }^{113}$.

Przyjazd do takiego miasteczka w środku nocy jest bardzo niebezpieczny. To okolice Treblinki. Chłopi zdziczeli, stali się nieprzewidywalni. Furmanki nie można wynająć, bo most na Bugu jest zerwany. Poszedłem nad rzekę piechotą, przeprawiłem się na drugi brzeg i w Prostyni wynająłem furmankę do Kosowa ${ }^{114}$

- opisywał swoją podróż.

Chłop, który go wziął ze sobą, uznał go za swojego, poczęstował bimbrem i wkrótce rozgadał się na tyle, że reporter odważył się zapytać: „Słyszałem, że kosowscy chłopi przyjeżdżali tutaj szukać złota?", na co ten odpowiedział:

${ }^{109}$ Canin zabrał ze sobą ten bucik, znalazł się on później w wykazie rzeczy sporządzonym podczas jego zatrzymania przy wyjeździe z Polski (idem, Przez ruiny i zgliszcza...., s. 499).

${ }^{110}$ Ibidem, s. 448-449.

111 Ibidem, s. 447-448.

112 Ibidem, s. 449.

113 Ibidem, s. 234.

${ }^{114}$ Ibidem. 
0, nie tylko kosowscy. Nawet z tamtej strony Bugu przyjeżdżali. Ale nasza gmina powiedziała: „wynocha!”. Co się znajdzie, to nasze. Ci z Kosowa się upierali, że ta ziemia należy do powiatu i też mają prawo szukać115.

Swój wywód o tym, że jego gmina była bardziej uprawniona do przekopywania cmentarzyska niż kosowska ze względu na większe zniszczenia (chodzi o gminę Prostyń), zakończył opisem bójki o władzę nad terytorium obozowym:

Ledwie uszli z życiem, bo nas było więcej, z Prostyni, z Treblinki, z Wólki, ze wszystkich wiosek dookoła. Wyszliśmy z cepami i porachowaliśmy im kości, że ledwie się dowlekli do Kosowa ${ }^{116}$.

Woźnica opowiedział jeszcze Caninowi o wykorzystywaniu ludzkich popiołów z Treblinki do nawożenia okolicznych pól ${ }^{117}$.

Czy czas, jak i nasze aktualne doświadczenia, które nieuchronnie oddalają nas od powojennej rzeczywistości, uniemożliwiają nam również przyjęcie, że tak mogło się wydarzyć? Czy taki był tamten świat?

Cały teren podzielony był na działki. Ile ich było, trudno mi powiedzieć. Panował tam okropny smród i fetor. Ludzi kopali w gnijących ludzkich zwłokach. Szczególnie oglądano szczęki ludzkie, szukając w nich złotych zębów i koronek. Rozłożone ludzkie wnętrzności były dokładnie przeszukiwane, gdyż ludzie wiedzieli, że Żydzi złoto często połykali. Widok niektórych ludzi nurzających się w tej ludzkiej mazi, jedzących w przerwie oblepionymi rękami był odrażający

- to niedatowana relacja świadka, który na terenie obozu był raz i więcej tam nie wrócił ${ }^{118}$. Według opowieści Zbigniewa Smikally, zawiadowcy stacji Małkinia w czasie drugiej wojny światowej, na obszar obozowy podążały tłumy.

Jechaliśmy pewnego razu wojskowym transportem radzieckim do Sokołowa, widzieliśmy wtedy tłumy ludzkie zdążających do Treblinki. Byliśmy świadkami bójki między kopiącymi, jeden z nich został uderzony w głowę. Co się stało z nim, tego nie wiem ${ }^{119}$.

Niestety, ta relacja również nie jest datowana, ale Smikalla twierdził, że wśród przybywających na teren obozu znajdowali się ludzie m.in. z Warszawy, Makowa i Krakowa.

Trudno zarzucać zatem Caninowi, że mógł przesadzić. Zauważmy zresztą, że wszystkie przytaczane świadectwa są zaskakująco zbieżne. Źródła wyjaśniają

115 Ibidem, s. 235.

${ }^{116}$ Ibidem.

${ }^{117}$ Ibidem, s. 236.

${ }^{118}$ Janusz Piwowar, Obóz zagłady w Treblince $w$ nieznanych dotychczas relacjach, „Podlaski Kwartalnik Kulturalny" 1994, nr 3, relacja Józefa Grzymały, mieszkańca Żoch, s. 71. Żochy leżą $17 \mathrm{~km}$ od Treblinki.

${ }^{119}$ Ibidem. 
też, dlaczego Grossman po przybyciu na teren obozu we wrześniu 1944 r. widział tam tak wielki chaos. Okoliczni chłopi zaczęli bowiem swoją „pracę” zaraz po ucieczce wartowników, w sierpniu tego samego roku. „Od razu zaczęło się wielkie kopanie. Najpierw po nocy ryli, potem to już jawnie: szli niby na wykopki ziemniaków - całe rodziny z widłami, łopatami, koszami, jedzeniem na obiad" - to kolejna relacja potwierdzająca wskazane wyjaśnienie, z Wólki Okrąglik ${ }^{120}$.

W tym miejscu należałoby przytoczyć jeszcze jeden przypadek osoby związanej z profanacją grobów, którą opisano w aktach. Chodzi o Franciszka D., w 1945 r. 16-latka, zatrzymanego przez PUBP w Dzierżoniowie w 1949 r. Jego wiek w roku zakończenia wojny jest istotny z tego względu, że wówczas prawdopodobnie, jak doniósł informator „S2", razem z członkami swojej rodziny „[z] jam, w których byli zakopani w obozie Tremblinki, wyrzucali trupy, rozcinali je, szukając brylantów i u niektórych znajdowali”121. Mogło się to dziać również w 1946 r., ponieważ w Bielawie, dolnośląskim miasteczku podlegającym PUBP Dzierżoniów, D. zamieszkał w listopadzie 1947 r. Po wyjeździe z rodzinnej wioski rozpoczął tam nowe życie. W miejscu, gdzie pracował, jego przytaczane wyżej wyznanie usłyszał informator służb bezpieczeństwa „S2”.

Franciszek D. mówił jeszcze o wymordowaniu żydowskiej rodziny ukrywającej się w czasie wojny u jego stryja. W okresie prowadzonego przez UB rozpracowania jego zwierzenia potwierdziło dwóch kolejnych świadków, w tym jego najbliższy kolega, z którym wyjechał z wioseczki Rytele-Wszołki ${ }^{122}$, oraz jeszcze inny informator. Ten ostatni był źródłem UB w więzieniu, gdzie D., jak wynika z akt, znalazł się we wrześniu 1949 r. Trudno powiedzieć, czy aresztowano go po rozpracowaniu, czy wcześniej. W aktach sprawy brakuje informacji o tym, jak przebiegały kolejne etapy śledztwa. Natomiast z dostępnych dokumentów wyłania się następujący szkic zatrzymanego. Całe życie mieszkał z rodzicami, czterema braćmi i siostrą; gdy skończył dwuoddziałową szkołę, ojciec zabrał go do pracy. W czasie wojny albo był świadkiem, jak jego najbliżsi zamordowali żydowską rodzinę lub kilka rodzin, albo przynajmniej o tym wiedział. Jedna z tych rodzin miała się ukrywać u jego stryja. Stryj i jego starszy brat, jak Franciszek D. powiedział w więzieniu współosadzonym, „mają na sumieniu kilka morderstw na tle rabunkowym, jak również po zamordowaniu wybijali zęby złote i ściągali biżuterię"123.

${ }^{120}$ Głuchowski, Kowalski, Goraczka złota $w$ Treblince... To relacja Eugeniusza Goski, pracującego w „gospodarstwie” po obozie. Dziennikarze dotarli do tego świadka, przygotowując tekst w 2008 r. Świadek pracował w „gospodarstwie” jako robotnik przymusowy. Jego zeznanie w tym zakresie znajduje się w United States Holocaust Memorial Museum (Poland Documentation Project, sygn. RG-50.225*0052, Zeznanie z 7 VII 1998 r.).

${ }^{121}$ AIPN, Wr 024/1486, Materiały dotyczące osoby podejrzewanej o morderstwa popełnione na Żydach i plądrowanie masowych grobów żydowskich w poszukiwaniu kosztowności, k. 12.

${ }^{122}$ Rytele-Wszołki - wieś w odległości 9 km od Treblinki.

${ }^{123}$ AIPN, Wr 024/1486, Wojewódzki Urząd Spraw Wewnętrznych, Materiały dotyczące osoby podejrzewanej o morderstwa popełnione na Żydach i plądrowanie masowych grobów żydowskich w poszukiwaniu kosztowności, k. 26. 
Po wojnie młody chłopak z najbliższymi sobie mężczyznami, autorytetami, przekopywał pozostałości obozu w Treblince. Przed wyjazdem do Bielawy - dokąd chciał się przenieść, by w związku z dorośnięciem młodszych braci przejść na własny rozrachunek - jego ojciec postanowił sprzedać znaleziony brylant wartości 1,5 mln zł ${ }^{124} \mathrm{i}$ kupić mu za to gospodarkę. Młodzieniec jednak nie chciał zostać. Po kłótni rodzinnej dostał swoją „odprawę” i wyjechał na Dolny Śląsk. W nowych warunkach przeszłość chyba za bardzo mu ciążyła. 0 „kosztownościach" trzymanych w domu rodzinnym mówił bez żadnej ostrożności. Nawet w celi prosił współwięźniów o załatwienie kartki i ołówka, zamierzał bowiem wysłać do rodziców list z prośbą, by „ukryli przedmioty złote, które mają w swoim posiadaniu"125. Finał tej sprawy pozostaje dotychczas nieodkryty.

\section{„Przez Treblinkę szły naprawdę ogromne skarby”}

W 1948 r. wbrew uspokajającym depeszom Żydowskiej Agencji Prasowej z poprzedniej jesieni proceder trwał nadal. 2 kwietnia 1948 r. Eugeniusz Dąbrowski, przewodniczący Powiatowej Rady Narodowej w Sokołowie Podlaskim, pisał do szefa tamtejszego PUBP: „Prezydium niniejszym załącza protokół komisyjnych oględzin b[yłego] obozu kaźni w Treblince do wiadomości, z prośbą o wydanie zarządzeń zmierzających w kierunku ukrócenia dalszej profanacji zwłok ofiar pomordowanych przez okupanta hitlerowskiego"126. W protokole sporządzonym po oględzinach terenu stwierdzono, że co prawda był ogrodzony, ale wciąż wyglądał źle. „Groby zbiorowe rozkopane są, a szczątki zwłok ludzkich są porozrzucane po całym terenie"127. Zauważmy, że nie ma tu mowy o ochronie wojskowej. Jeszcze gorzej przedstawiało się cmentarzysko ofiar Treblinki I, o którym poza raportem śledczego Łukaszkiewicza z $1945 \mathrm{r}$. chyba kompletnie zapomniano. „Nie jest ogrodzone i przez to w dalszym ciągu dostępne jest dla poszukiwaczy złota bezczeszczących zwłoki ludzkie. Groby w ilości około 50 są rozkopane, a czaszki, kości i resztki ubrań walają się wokoło rozkopanych grobów"128. Prezydium sokołowskiej PRN 2 kwietnia podjęło uchwałę - wniosek do wyższej instancji, by ten obszar też otoczyć płotem. Rachunek za „wykonanie robót na terenie cmentarzyska w Treblince nr 2" pochodzi z 4 lipca 1949 r. ${ }^{129}$

${ }^{124}$ Ibidem, k. 18.

125 Ibidem, k. 26.

${ }^{126}$ AP Siedlce, Powiatowa Rada Narodowa w Sokołowie Podlaskim 1944-1950, Protokoły posiedzeń PRN, 62, Protokół oględzin miejsca obozu kaźni „Treblinka”, k. 292.

${ }^{127}$ Ibidem, k. 293.

${ }^{128}$ Ibidem.

${ }^{129}$ AP Siedlce, Powiatowa Rada Narodowa w Sokołowie Podlaskim 1944-1950, 62, Inwestycje na ogrodzenie cmentarza w Treblince, k. 6. Zakupiono wówczas kilkadziesiąt słupów sosnowych i drut kolczasty. Teren otoczono płotem, zbudowano bramy i alejki do przechodzenia po terenie. 
Dokładne określenie momentu, kiedy „gorączka złota” wygasła albo stała się wąską domeną zawodowców, pozostaje zatem trudne. Jeszcze 3 czerwca $1954 \mathrm{r}$. podczas wizytowania byłego obozu przez komisję urzędników resortu kultury, muzealników, Towarzystwa Społeczno-Kulturalnego Żydów w Polsce oraz lokalnych władz odnotowano zniszczony płot wokół obozu, a na polu zatrzymano mieszkańca wsi Wólki Okrąglik ${ }^{130}$. W kadrach Polskiej Kroniki Filmowej z 1957 r. zatytułowanej Hieny widać ciągle ślady profanacji. Proceder zakończył się prawdopodobnie dopiero $\mathrm{w}$ momencie wybudowania pomnika ofiar $\mathrm{w}$ kwietniu $1963 \mathrm{r}$. Jego powszechność zmniejszała się też z racji normalizacji codziennego życia w PRL. Z analizy zebranych dokumentów można wysnuć wniosek, że największe natężenie profanacji trwało od sierpnia/jesieni 1944 do połowy $1947 \mathrm{r}$.

Zgromadzone dokumenty pozwalają wyłonić rozmaite wątki, ale powszechność procederu jest w tym obrazie wyraźna i znacząca. Pod pojęciem „powszechności" rozumiem przede wszystkim wyjście poza specjalizację wynikającą z określeń stosowanych wobec tych, którzy pojawili się na terenie byłego obozu. Określa się ich bowiem mianem „hien” lub „kopaczy”. „Hiena” to człowiek trudniący się określonym „fachem” - okradaniem grobów. „Kopacz” z kolei to również specjalista - poszukiwacz „żydowskiego złota”131. Obie nazwy na poziomie semantyki zawężają znaczeniowo grupy ludzi uczestniczących w profanacji. Wskazują na ich umiejętności czy wręcz rodzaj zawodu. Prowadzi to do ich wyraźnego wyodrębnienia w wymiarze kulturowym. Członkowie tych grup są naruszycielami „tabu trupa”, tak silnego na poziomie ogólnie pojętego człowieczeństwa. Przekraczają odwieczne sacrum. Granicę, za którą można się spotkać tylko z potępieniem ${ }^{132}$.

Tymczasem z dostępnych źródeł i akt wynika, że na terenach Treblinki pojawiali się nie tylko wyspecjalizowani handlarze, jak hieny, kopacze czy inni podobni im „fachowcy”, lecz także zwykli ludzie. Tacy jak Dominik K., idący tam z sąsiadami, a później chwalący się znalezieniem „brylanta” swojej żonie, czy Franciszek D., podążający na pole za bratem, stryjem i ojcem. Nie byli to zawodowcy, ale przypadkowi ludzie z bliskiej obozowi wsi. Co takiego wydarzyło się zatem na polach Treblinki, że społeczność z tak głęboko zakorzenionym „tabu trupa" była gotowa go naruszyć w takiej skali?

W tym kontekście niezwykle ważna wydaje się wskazówka Racheli Auerbach, dostrzegającej podobieństwo „gorączki” na polach Treblinki do klasycznej „gorączki złota". Upiornymi złożami złota były tutaj resztki ciał, wymieszane z pia-

${ }^{130}$ Rusiniak, Obóz zagłady Treblinka II w pamięci społecznej..., s. 39.

${ }^{131}$ Martyna Rusiniak używa sformułowania „hieny ludzkie”, a Piotr Głuchowski i Marcin Kowalski posługują się określeniem „kopacze”.

${ }^{132}$ Adam Fischer w książce o ludowych obyczajach pogrzebowych poświęcił temu rozdział pt. „Trup jako tabu”. Tam m.in.: „Zwłoki mogą skalać nie tylko ogień, ale w ogóle wszystko, cokolwiek się w domu znajduje [...] gdy umarły w domu leży, trzeba usunąć wszelkie jedzenie, bo przejdzie «trupem»" (Adam Fischer, Zwyczaje pogrzebowe ludu polskiego, Lwów: Zakład Narodowy im. Ossolińskich, 1921, s. 131-132). 
chem i popiołem, legendami o złotych kolczykach, brylantach, kosztownościach, w rzeczywistości najbardziej bliskich lub wartościowych „ruchomościach tułacza"133 - zabieranych przez ofiary w ostatnią drogę, na ostatnią chwilę. Pisała:

Przewidziałam, że miejsce żydowskiej Zagłady stanie się kiedyś polskim Klondike, dokąd z całego kraju przybywać będą wszelkiej maści awanturnicy, by kopać w ziemi i szukać skarbów. Przez Treblinkę szły naprawdę ogromne skarby. Setki tysięcy ludzi przybywały z tym, co posiadali najlepszego i najdroższego. „Złoto i waluta mogą zostać zabrane” - pisano na afiszach „wysiedleńczych" w Warszawie i innych miastach $[\ldots]^{134}$.

Przyjmując powyższe konkluzje, nie można zapominać o statusie podlaskiego chłopa, który od wieków oglądał biedę z każdej możliwej strony i sam jej doświadczał, a po drugiej wojnie światowej warunki jego życia na Podlasiu stały się szczególnie trudne. Co dla chłopa mogło być skarbem? Czy było nim odbudowanie domu? Zmiana dachu ze strzechy na blachę? Kupno nowych butów lub butelki wódki? Worka mąki? Albo konia czy krowy? Okoliczności, jakie mogły towarzyszyć każdej jednostkowej bądź zbiorowej decyzji o wyruszeniu na teren obozu, były różne. Nie jest to próba usprawiedliwienia profanacji. Raczej poszukiwanie odpowiedzi, dlaczego tak się stało. Tak jak istotne pozostaje zbadanie innych wątków: spontanicznej lub kryminalnej organizacji procederu, systemu pośredników czy zadziwiającego paraliżu organów ścigania.

Suma wskazanych aspektów i obserwacji związanych z przekopywaniem, szukaniem i ryciem ${ }^{135}$ pól Treblinki w obliczu odnalezionych niedawno dokumentów może stanowić istotny trop w dalszych badaniach tego procesu. Jednym z najważniejszych ustaleń w ramach niniejszego artykułu wydaje się rozmiar procederu, co w istotny sposób może zmienić dotychczasowe rozważania na temat jego przyczyn i skutków.

\section{BIBLIOGRAFIA}

\section{Źródła archiwalne}

\section{Archiwum Instytutu Pamięci Narodowej}

00495/57, Meldunki specjalne Komendy Powiatowej MO Sokołów Podlaski 1945 00495/79, Meldunki specjalne nadsyłane z KP MO w Sokołowie Podlaskim do Komendy Milicji Obywatelskiej Województwa Warszawskiego

133 „Żydzi - jako doświadczony od pokoleń naród tułaczy zwłaszcza od czasu wojny i wysiedleń, od czasu kiedy już wiedzieli, że w ciągu pół godziny można nakazać wyjście i porzucenie wszystkiego - starali się jak najwięcej swojego majątku nieruchomego ulokować w ruchomym. I tym najbardziej ruchomym: złocie, biżuterii i dolarach. Czy to oznacza, że Żydzi są rzeczywiście narodem samych bogaczy? W żadnym razie!" (Auerbach, Treblinka. Reportaż..., s. 70-71). To dłuższy wywód opisujący wybory i zachowania wobec zacieśniania represji wobec ludności żydowskiej w czasie II wojny światowej.

134 Ibidem, s. 70.

${ }^{135}$ Ibidem, s. 72. 
0446/9, Raport dekadowy PUBP Sokołów Podlaski 1946

GK 166/1185, Spis ofiar II wojny światowej 1939-1945 powiatu Sokołów Podlaski

GK 196/69, Protokół czynności wykonanych w terenie w toku dochodzenia sądowego w sprawie obozu śmierci w Treblince

GK 196/69, Protokół oględzin bilonu stanowiącego dowód rzeczowy

GK 196/69, Wykaz przesłanych do Sądu Grodzkiego dowodów rzeczowych dotyczących obozu w Treblince

GK 196/70, Protokół oględzin przedmiotów pochodzących z obozu śmierci w Treblince

Wr 024/1486, Wojewódzki Urząd Spraw Wewnętrznych

\section{Archiwum Państwowe w Warszawie Oddział w Milanówku}

Urząd Wojewódzki Warszawski 1944-1950, Wydział Społeczno-Polityczny

72/500/511

Profanacja Treblinki, 259

\section{Archiwum Państwowe w Siedlcach}

Gmina Prostyń, 62/261, 100

Powiatowa Rada Narodowa w Sokołowie Podlaskim 1944-1950, 62

Sąd Okręgowy, 580

Starostwo Powiatowe Węgrowskie, Referat Społeczno-Polityczny, Różne, 62/162

\section{Archiwum Żydowskiego Instytutu Historycznego}

„Biuletyn Żydowskiej Agencji Prasowej”

301/4867, Protokół Michała Kalembasiaka i Karola Ogrodowczyka dla WŻKH w Warszawie

302/321, Mirosław Chodźko, „Treblinka dziś”

\section{United States Holocaust Memorial Museum}

Poland Documentation Project, sygn. RG-50.225*0052

\section{Źródła publikowane}

Auerbach Rachela, Treblinka. Reportaż, tłum. Karolina Szymaniak, „Zagłada Żydów. Studia i Materiały" 2012, nr 8 [pierwodruk: Ojf di felder fun Treblinke [Na polach Treblinki], Łódź: CŻKH, 1947].

Canin Mordechaj, Przez ruiny i zgliszcza. Podróż po stu zgładzonych gminach żydowskich w Polsce, tłum. i oprac. Monika Adamczyk-Garbowska, Warszawa: Nisza i ŻIH, 2018.

Grossman Wasilij, Piekło Treblinki. Reportaż literacki, Katowice: Literatura Polska, 1945.

Kirszenbaum Chil, Moje notatki z piekła. Bestialskie wymordowanie Żydów w Mińsku Mazowieckim, Warszawa: Przedsiębiorstwo Wydawniczo-Handlowe „Graf”, 2006.

Łukaszkiewicz Zdzisław, Streszczenie wyników śledztwa sq̨dowego, „Biuletyn Głównej Komisji Badania Zbrodni Niemieckich w Polsce" 1946, t. 1.

Piwowar Janusz, Obóz zagłady w Treblince $w$ nieznanych dotychczas relacjach, „Podlaski Kwartalnik Kulturalny" 1994, nr 3.

\section{Literatura przedmiotu}

Dziuban Zuza, Atopic objects: The afterlives of gold teeth stolen from Holocaust death, „Journal of Material Culture" 2020, t. 25, nr 4. 
Fischer Adam, Zwyczaje pogrzebowe ludu polskiego, Lwów: Zakład Narodowy im. Ossolińskich, 1921.

Głuchowski Piotr, Kowalski Marcin, Gorq̨czka złota w Treblince, „Gazeta Wyborcza”, dodatek „Duży Format”, 8 I 2008.

Gross Jan Tomasz, współpraca Irena Grudzińska-Gross, Złote żniwa. Rzecz o tym, co się działo na obrzeżach zagłady Żydów, Kraków: Znak, 2011.

Reszka Paweł Piotr, Płuczki. Poszukiwacze żydowskiego złota, Warszawa: Agora, 2019.

Rusiniak Martyna, Obóz zagłady Treblinka II w pamięci społecznej (1943-1989), Warszawa: Neriton, 2008.

Rusiniak-Karwat Martyna, Okres profanacji i zapomnienia. Treblinka II [w:] Co wiemy o Treblince? Stan badań, red. Edward Kopówka, Siedlce: Muzeum Regionalne w Siedlcach, 2013.

Sturdy Colls Caroline, 0 tym, co minęło, lecz nie zostało zapomniane. Badania archeologiczne na terenie byłego obozu zagłady w Treblince, tłum. Ewa Felska, Jerzy Giebułtowski, „Zagłada Żydów. Studia i Materiały” 2012, nr 8.

Witt Kazimierz, Sokołów Podlaski w latach 1939-1950 [w:] Dzieje Sokołowa Podlaskiego i jego regionu, red. Józef Kazimierski, Warszawa: PWN, 1982. 